Report of Investigation 2019-7

\title{
REGIONAL TSUNAMI HAZARD ASSESSMENT FOR THE COMMUNITIES OF PORT ALEXANDER, CRAIG, AND KETCHIKAN, SOUTHEAST ALASKA
}

E.N. Suleimani, J.B. Salisbury, D.J. Nicolsky, and R.D. Koehler

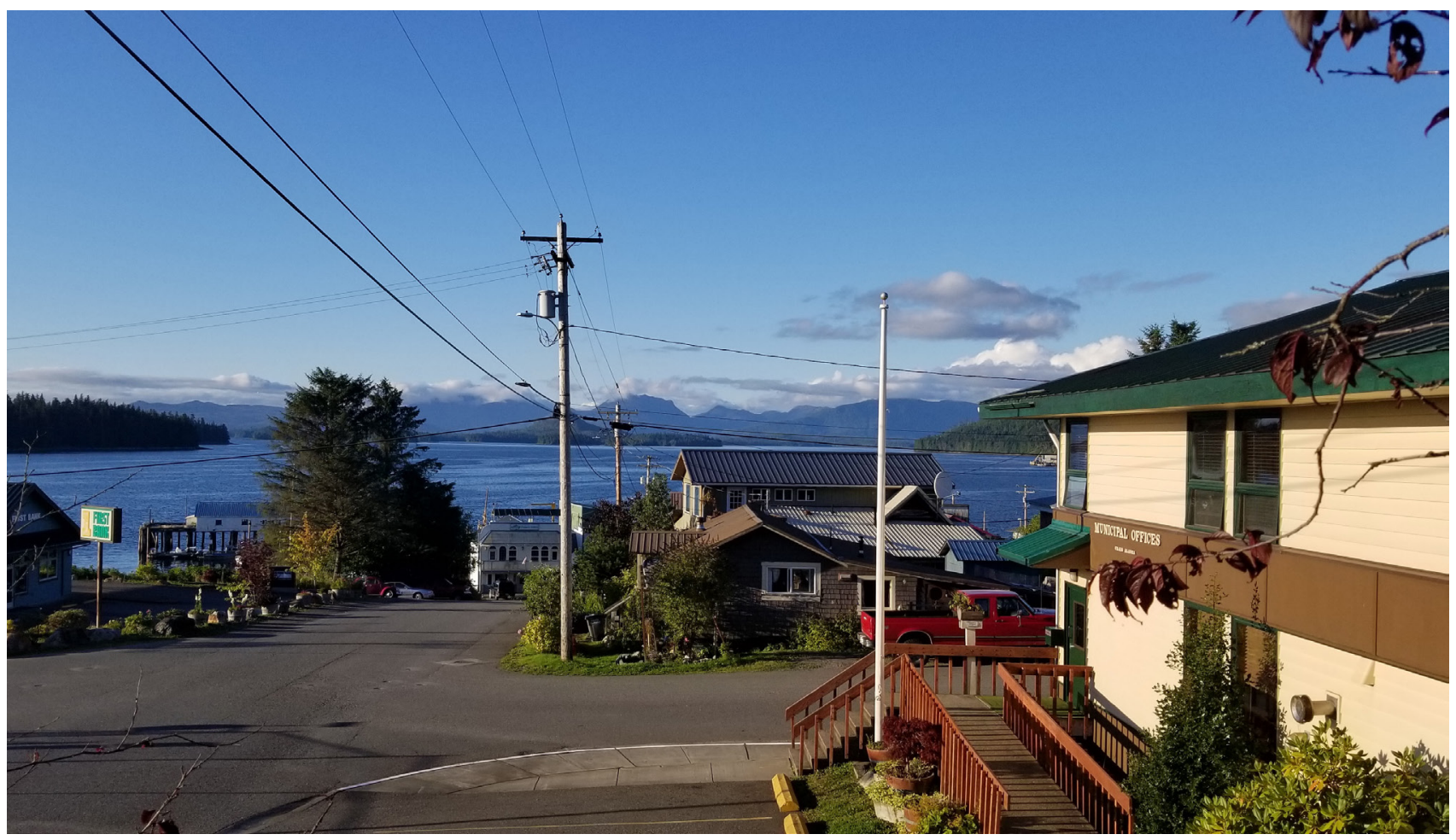

Craig, Alaska. Photo: Elena Suleimani. 



\section{REGIONAL TSUNAMI HAZARD ASSESSMENT FOR THE COMMUNITIES OF PORT ALEXANDER, CRAIG, AND KETCHIKAN, SOUTHEAST ALASKA}

E.N. Suleimani, J.B. Salisbury, D.J. Nicolsky, and R.D. Koehler

Report of Investigation 2019-7

State of Alaska

Department of Natural Resources

Division of Geological \& Geophysical Surveys 
STATE OF ALASKA

Michael J. Dunleavy, Governor

\title{
DEPARTMENT OF NATURAL RESOURCES
}

Corri A. Feige, Commissioner

\section{DIVISION OF GEOLOGICAL \& GEOPHYSICAL SURVEYS}

\author{
Steve Masterman, State Geologist and Director
}

Publications produced by the Division of Geological \& Geophysical Surveys (DGGS) are available for free download from the DGGS website (dggs.alaska.gov). Publications on hard-copy or digital media can be examined or purchased in the Fairbanks office:

Alaska Division of Geological \& Geophysical Surveys 3354 College Rd., Fairbanks, Alaska 99709-3707

Phone: (907) 451-5010 Fax (907) 451-5050

dggspubs@alaska.gov|dggs.alaska.gov

DGGS publications are also available at:

Alaska State Library,

Historical Collections \& Talking Book Center

395 Whittier Street

Juneau, Alaska 99811

Alaska Resource Library and Information Services (ARLIS)

3150 C Street, Suite 100

Anchorage, Alaska 99503

Suggested citation:

Suleimani, E.N., Salisbury, J.B., Nicolsky, D.J., and Koehler, R.D., 2019, Regional tsunami hazard assessment for the communities of Port Alexander, Craig, and Ketchikan, Southeast Alaska: Alaska Division of Geological \& Geophysical Surveys Report of Investigation 2019-7, 23 p., 5 sheets. doi.org/10.14509/30196

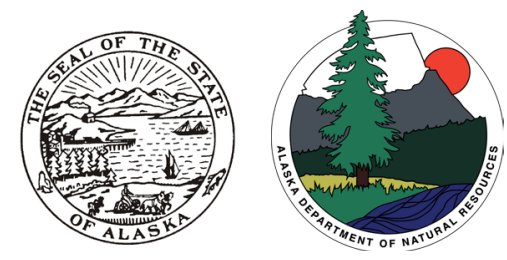




\section{Contents}

Abstract ton

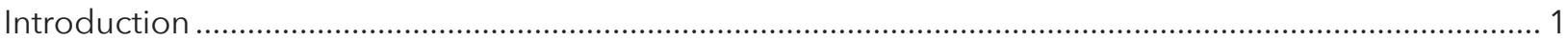

Project Background: Regional and Historical Context...................................................................... 3

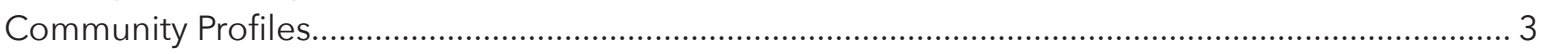

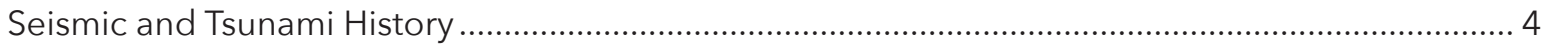

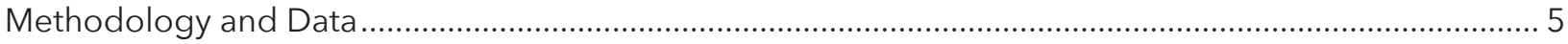

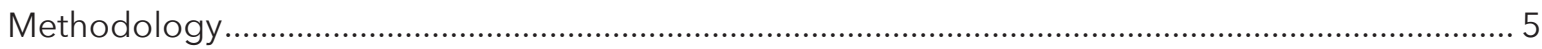

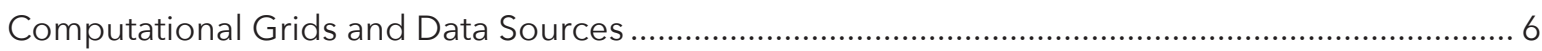

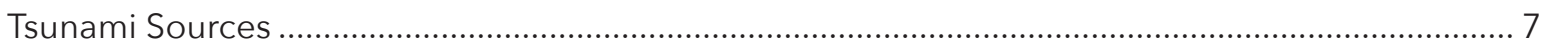

Scenario 1. $A \mathrm{M}_{\mathrm{W}} 9.3$ event: Extended 1964 rupture.......................................................... 9

Scenario 2. $A M_{W} 9.2$ event: Earthquake in the 1964 rupture area with Tohoku-

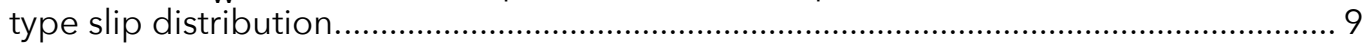

Scenario 3. $A M_{W} 9.0$ event: The SAFRR tsunami scenario..................................................... 9

Scenario 4. $A \mathrm{M}_{\mathrm{W}} 9.0$ event: Rupture of the Cascadia subduction zone............................. 9

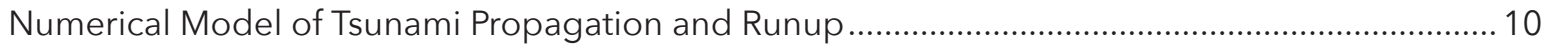

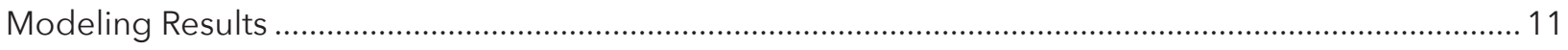

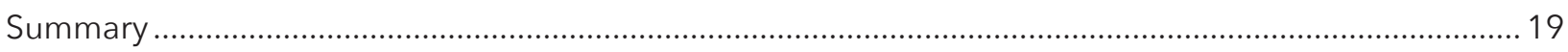

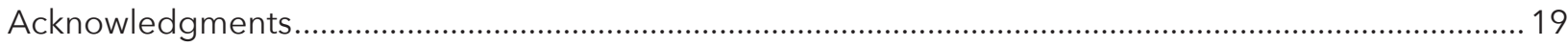

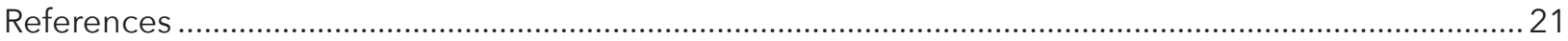

\section{Figures}

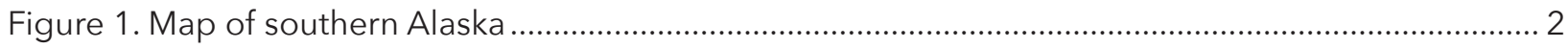

Figure 2. Map of Southeast Alaska showing locations of the three communities...................................... 4

Figure 3. Nesting of the bathymetry/topography grids for numerical modeling of tsunami

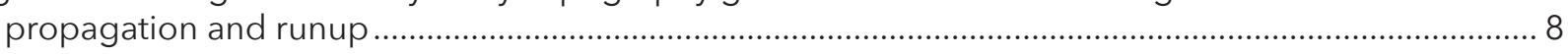

Figure 4. Vertical coseismic deformations corresponding to scenarios 1-4 ....................................... 10

Figure 5. Maximum tsunami heights for scenarios 1-4 in the Port Alexander level 3 grid ...................... 12

Figure 6. Maximum tsunami heights for scenarios 1-4 in the Craig/Ketchikan level 3 grid.................... 14

Figure 7. Maximum composite tsunami height at Port Alexander, Craig, and Ketchikan........................ 16

Figure 8. Time series of water level for scenarios 1-4 at Port Alexander, Craig, and Ketchikan .............. 20

\section{Tables}

Table 1. Tsunami effects at the three Southeast communities

Table 2. Nested grids used to compute propagation of tsunami waves generated in the Pacific

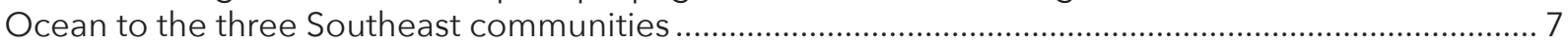

Table 3. Significant credible tsunami sources for the three Southeast communities................................ 8

Table 4. Summary of tsunami modeling results for the three Southeast communities ........................... 14

\section{Map Sheets}

Sheet 1. Tsunami hazard map of Pot Alexander, Alaska

Sheet 2. Tsunami hazard map of Craig, Alaska

Sheet 3. Tsunami hazard map of Ketchikan, Alaska

Sheet 4. Tsunami hazard map of Peninsula Point and Ward Cove, Alaska

Sheet 5. Tsunami hazard map of Saxman and Mountain Point, Alaska 



\title{
REGIONAL TSUNAMI HAZARD ASSESSMENT FOR THE COMMUNITIES OF PORT ALEXANDER, CRAIG, AND KETCHIKAN IN SOUTHEAST, ALASKA
}

\author{
E.N. Suleimani, ${ }^{1}$ J.B. Salisbury, ${ }^{2}$ D.J. Nicolsky, ${ }^{1}$ and R.D. Koehler ${ }^{3}$
}

\begin{abstract}
We assess potential tsunami hazard for three coastal communities in Southeast Alaska: Port Alexander, Craig, and Ketchikan. The primary tsunami hazard for these communities is considered to be far-field, with the major threat originating from tsunamigenic earthquakes along the Alaska-Aleutian subduction zone across the Gulf of Alaska. We numerically model tsunami waves generated by four different megathrust earthquakes and develop approximate tsunami hazard maps for the three communities. The hypothetical tsunami scenarios that we examined include variations of an extended 1964 rupture, megathrust earthquakes in the Prince William Sound and Alaska Peninsula regions, and a Cascadia megathrust earthquake. The maximum runup heights are $4 \mathrm{~m}(13.1 \mathrm{ft})$ in Port Alexander, $3.2 \mathrm{~m}(10.5 \mathrm{ft})$ in Craig, and $1 \mathrm{~m}$ (3.3 ft) in Ketchikan. Results presented here are intended to provide guidance to local emergency management agencies in initial tsunami inundation assessment, evacuation planning, and public education for mitigation of future tsunami hazards.
\end{abstract}

\section{INTRODUCTION}

Tsunami hazards along Alaska’s Pacific coastline are high. Virtually all of Alaska's southern and southeastern coasts are defined by major offshore fault systems. Unlike tsunamis that are caused by distant earthquakes on the other side of the Pacific, Alaska's greatest tsunami hazards originate just offshore and can inundate coastlines within an hour of a causative earthquake. This reduces the time available to respond and evacuate, and can produce drastically higher wave heights than far-traveled tsunamis. Many Alaska communities hug the shoreline (due to some combination of steep mountains, dense forests, and/or reliance on the open water for transportation), many Alaska communities are within the tsunami inundation zone and are at risk of rapid flooding. In addition to earthquake-generated (i.e., tectonic) tsunamis, mass movements of sediments down slopes (either on land or in the ocean) can also generate tsunamis. While rapid tsunami flooding is the immediate concern after a large coastal earthquake, dangerous near-shore ocean currents and permanent changes to the local coastline are additional concerns.

The local, tectonic tsunami danger to communities in Southeast Alaska comes primarily from two fault systems that span the entire southern and southeastern coasts of Alaska (fig. 1). The Alaska-Aleutian subduction zone, spanning more than $3,800 \mathrm{~km}$ (2,360 mi), extends from the westernmost Aleutian Islands to nearly the Canadian border at $141^{\circ} \mathrm{W}$ longitude. This subduction zone marks the boundary between the Pacific plate to the south and the North American plate to the north. Relative to the North American plate, the Pacific Plate is moving northwest at approximately $5-8 \mathrm{~cm}$ (2-3 inches) per year,

${ }^{1}$ Alaska Earthquake Center, Geophysical Institute, University of Alaska, P.O. Box 757320, Fairbanks, Alaska 99775-7320; ensuleimani@alaska.edu

${ }^{2}$ Alaska Division of Geological \& Geophysical Surveys, 3354 College Rd., Fairbanks, Alaska 99709-3707.

${ }^{3}$ Nevada Bureau of Mines and Geology, Mackay School of Earth Science and Engineering, University of Nevada, Reno, 1664 North Virginia Street, MS 178, Reno, NV 89557 


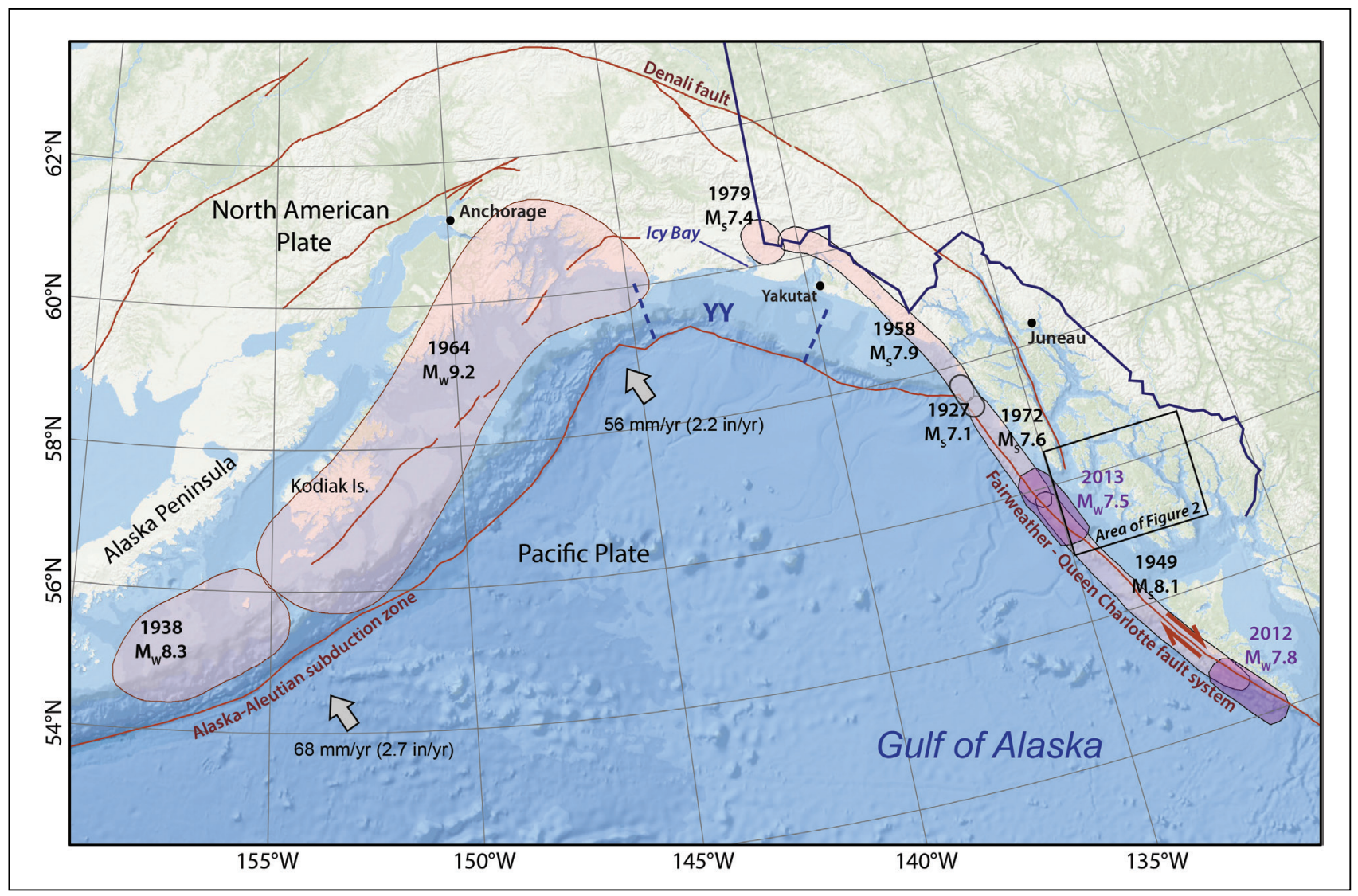

Figure 1. Map of southern Alaska. The rupture areas of significant earthquakes are shown by pink-shaded polygons. The most recent earthquakes of 2012 and 2013 are shown by purple-shaded polygons. Black rectangle outlines the area shown in figure 2. Red lines indicate active faults.

colliding with the North American plate and diving beneath it in a process known as subduction. East of the subduction zone the fault orientation and style of deformation are starkly different. The second major fault system begins in the Gulf of Alaska and extends $1,000+\mathrm{km}(620+\mathrm{mi})$ southeast along the coastlines of Alaska and Canada. Known as the Fairweather and Queen Charlotte faults, respectively, this system (F-QC for short) primarily accommodates right lateral strike-slip (i.e., side-to-side) motion between the Pacific and North American plates.

The specifics of tsunami hazards are particular to each community and vary considerably over large regions. The shape of the coastline, local bathymetry, and topography all affect tsunami impacts. More importantly, however, is the earthquake source (the location, size, and style) being considered and the community's location relative to that earthquake.
For subduction zone earthquakes, communities in Southeast Alaska can generally expect a tsunami crossing the Gulf of Alaska to take an hour or more to reach their shores. Earthquakes along the F-QC system pose a much more immediate tsunami threat, with travel times measured in minutes instead of hours. Fortunately, strike-slip earthquakes (those characteristic of the F-QC system) do not typically deform the seafloor vertically and therefore are less likely to produce significant tsunamis. However, strong earthquake shaking in Southeast Alaska may cause landslides, either from steep fjord cliffs or underwater slopes, that can generate locally significant tsunamis. We do not address any landslide-generated tsunamis in this report.

The impacts of future earthquakes and tsunamis can be reduced if citizens, emergency managers, and city planners take steps to mitigate the hazards. This 
report is intended to support hazard mitigation efforts by providing approximate tsunami hazard estimates for the communities of Port Alexander, Craig, and Ketchikan. The scenario earthquakes, numerical tsunami models, and resulting maps are developed on a regional level and lack the precision of studies that are fully tailored to individual communities (e.g., Nicolsky and others, 2013; Nicolsky and others, 2014; Suleimani and others, 2013, 2015). The current study does not include sensitivity tests and is based on four scenario earthquakes. Even so, the results provide a good first approximation of tsunami hazard. The maps, documentation, and available digital data provide a foundation for public education, support the development of evacuation procedures, and provide insights intended to improve community resilience.

\section{PROJECT BACKGROUND: REGIONAL AND HISTORICAL CONTEXT \\ Community Profiles}

The following information is paraphrased from the Alaska Community Database Online provided by the Alaska Department of Commerce, Community, and Economic Development, Division of Community and Regional Affairs (DCCED/DCRA, 2013).

Port Alexander (59 $\left.14^{\prime} 24^{\prime \prime} \mathrm{N}, 134^{\circ} 39^{\prime} 26^{\prime \prime W}\right)$, population 52, is a fishing community located at the south end of Baranof Island, 142 miles south of Juneau. It is an icefree port during the winter. The site was named in 1849 by Capt. M.D. Tebenkov, Governor of the Russian American colonies. In 1913, salmon trollers began using the rich fishing grounds of the South Chatham Strait area as a seasonal base. Two floating processors arrived soon after. By 1916, there was a fishing supply store, a shore station owned by Northland Trading and Packing Company, and a bakery at Port Alexander. During the 1920s and '30s, a year-round community had evolved around the prosperous fishing fleet.
Beginning in 1938, fish stocks declined dramatically and processing became uneconomical. The outbreak of World War II essentially collapsed the town's economy. In the 1970s, state land disposal sales and upswings in salmon stocks enabled new families to build and settle in the community. The city incorporated in 1974 and detached from the City and Borough of Sitka during that year.

Craig $\left(55^{\circ} 28^{\prime} 35^{\prime \prime} \mathrm{N}, 133^{\circ} 08^{\prime} 54^{\prime \prime} \mathrm{W}\right)$, population 1,201 , is located on a small island off the west coast of Prince of Wales Island and is connected by a short causeway. The Tlingit and Haida peoples have historically utilized the area around Craig for its rich resources. Between 1908 and 1911, the Lyndenburger Packing Company and cold storage plant were constructed at the present site of Craig. In 1912, a post office, school, sawmill, and salmon cannery were constructed. Production at the cannery and sawmill peaked during World War I. A city government was formed in 1922. Excellent pink salmon runs contributed to development and growth through the late 1930s. During the 1950s, the fishing industry collapsed due to depleted salmon runs. In 1972, Ed Head built a large sawmill six miles from Craig near Klawock, which provided year-round jobs and helped to stabilize the economy. Craig is predominantly a fishing community.

Ketchikan $\left(55^{\circ} 21^{\prime} \mathrm{N}, 131^{\circ} 40^{\prime} 24^{\prime \prime} \mathrm{W}\right)$, population 8,050 , is located on the southwestern coast of Revillagigedo Island near the southern boundary of Alaska, 235 miles south of Juneau. Ketchikan's airport is located on Gravina Island, across the Tongass Narrows. The 2.2-million-acre Misty Fjords National Monument lies 22 air miles east of Ketchikan. It is the first Alaska port of call for northbound cruise ships and state ferries. The first cannery opened in 1886 near the mouth of Ketchikan 
Creek and four more were built by 1912 . The Ketchikan Post Office was established in 1892, and the city was incorporated in 1900. By this time, nearby gold and copper discoveries had briefly brought activity to Ketchikan as a mining supply center. During 1936, seven canneries were in operation, producing 1.5 million cases of salmon. This booming fishing industry played a significant part in Ketchikan's history and economic development throughout the years. The need for lumber for new construction and salmon packing boxes spawned the Ketchikan Spruce Mills in 1903, which operated for more than 70 years. Recently the tourism industry in Ketchikan has become one of the town's largest sources of revenue, with nearly one million cruise ship visitors per year. Large cruise passenger vessels began to visit Ketchikan regularly in the 1960 s, and the supporting industry has grown steadily since then.

\section{Seismic and Tsunami History}

Historic and geologic records of earthquakes and tsunamis in Southeast Alaska are dominated by the great $(M>8)$ earthquakes of the Alaska-Aleutian subduction zone (Dunbar and Weaver, 2008). Several historic megathrust earthquakes have caused tsunamis resulting in widespread damage and loss of life in south-central Alaska and throughout the Pacific (Lander, 1996). The latest sequence of great

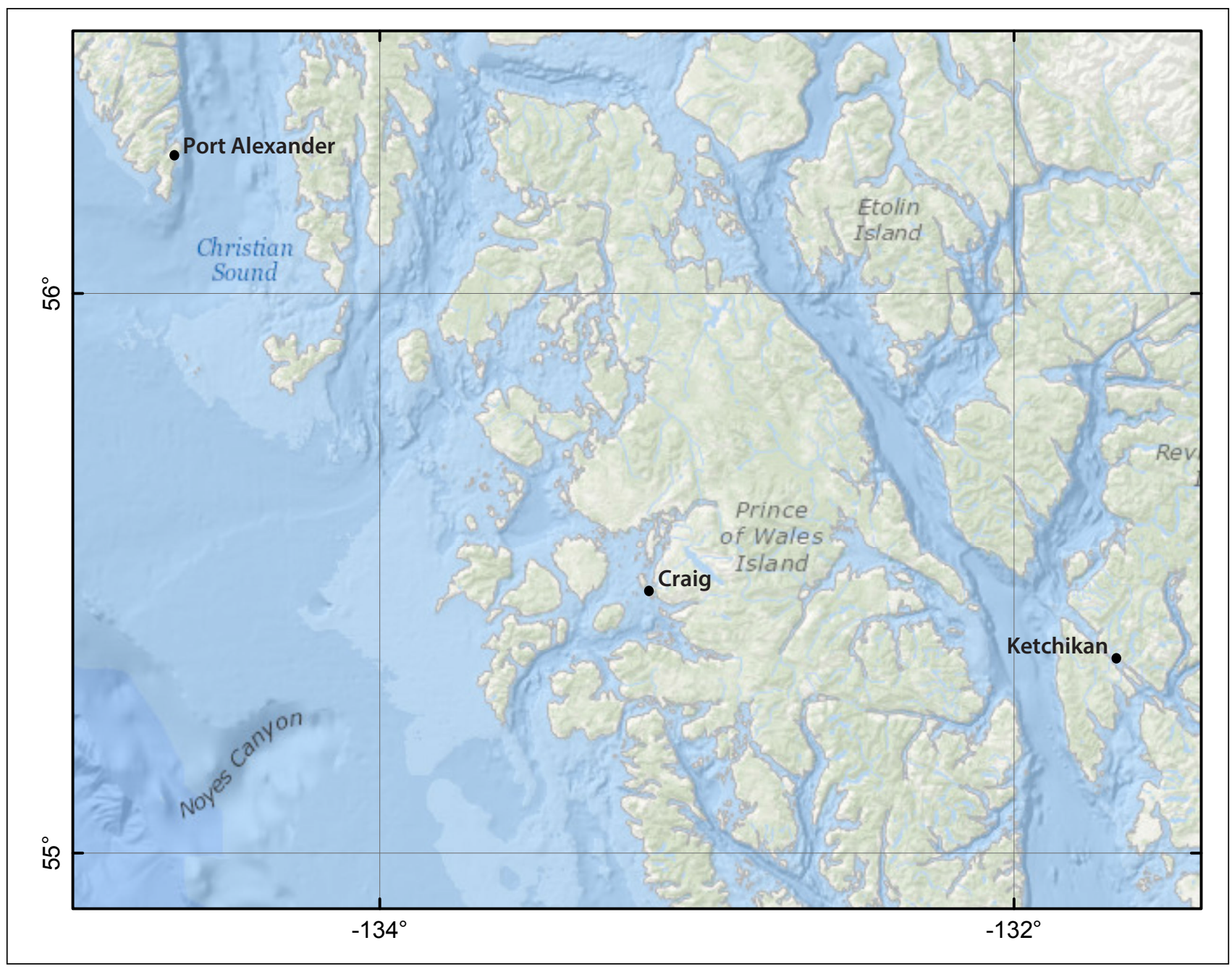

Figure 2. Map of Southeast Alaska showing locations of the three communities of Port Alexander, Craig, and Ketchikan. 
megathrust earthquakes (Carver and Plafker, 2008) appears to have begun in 1938 with a $\mathrm{M}_{\mathrm{W}} 8.3$ earthquake west of Kodiak Island (Estabrook and others, 1994; fig. 1). Four subsequent events-the $1946 \mathrm{M}_{\mathrm{W}}$ 8.6 Eastern Aleutian (Lopez and Okal, 2006), 1957 $\mathrm{M}_{\mathrm{W}}$ 8.6 Andreanof Islands (Johnson and others, 1994), $1964 \mathrm{M}_{\mathrm{W}} 9.2$ Great Alaska (Kanamori, 1970), and $1965 \mathrm{M}_{\mathrm{W}}$ 8.7 Rat Island (Wu and Kanamori, 1973) earthquakes — ruptured much of the length of the subduction zone.

The 1946 Eastern Aleutian Islands earthquake killed 159 people in Hawaii and caused \$26 million in damage. The earthquake was the impetus for founding the Pacific Tsunami Warning Center in Hawaii. The 1964 M 9.2 Great Alaska Earthquake devastated communities across Alaska's southern coast. The tsunami from this event killed 106 in Alaska and an additional 12 people in California (Lander, 1996), and was the driving force for establishing the Alaska/West Coast Tsunami Warning Center. The tsunami struck many communities in southeast Alaska causing varying degrees of damage but no loss of life (Lander, 1996).

The Fairweather-Queen Charlotte fault system that parallels the Southeast Alaska coastline also has a long history of producing large earthquakes. Most of the fault system has ruptured in large strike-slip earthquakes over the past century: $1927\left(\mathrm{M}_{\mathrm{S}} 7.1\right), 1949$ $\left(\mathrm{M}_{\mathrm{s}}\right.$ 8.1), $1958\left(\mathrm{M}_{\mathrm{s}} 7.9\right)$, and $1972\left(\mathrm{M}_{\mathrm{s}} 7.6\right)$ (Page, 1973; Sykes, 1971; Tocher, 1960; figure 1). Several of these earthquakes generated tsunamis. The 1958 earthquake triggered a large landslide into Lituya Bay that generated a 530-m-high (1,740-ft-high) wave (Miller, 1960). The 2012 Haida Gwaii earthquake occurred along a convergent section of the Queen Charlotte fault. Uplift of the seafloor during the Haida Gwaii earthquake generated a tsunami that exceeded $6 \mathrm{~m}(20 \mathrm{ft})$ of runup at a number of sites, and measured $0.8 \mathrm{~m}(2.6 \mathrm{ft})$ at a tide gauge in Hawaii (Leonard and Bednarski, 2015). The most recent large earthquake on the F-QC system, the January 5, 2013, $\mathrm{M}_{\mathrm{W}}$ 7.5 Craig earthquake, produced only modest local tsunamis but was sufficient to initiate tsunami evacuations in several communities.
Table 1 summarizes all historically recorded earthquakes that produced tsunamis larger than 10 $\mathrm{cm}$ (4 in) at the evaluated communities (National Centers for Environmental Information [NCEI] and National Oceanic \& Atmospheric Administration [NOAA] Global Historical Tsunami Database [doi.org/10.7289/V5PN93H7] and Lander, 1996).

\section{METHODOLOGY AND DATA Methodology}

The regional tsunami hazard maps presented here are the product of collaborative efforts between state and federal agencies to assist coastal communities in Alaska with tsunami hazard assessment. In recent years, similar tsunami hazard studies have been published for other communities (Nicolsky and others, 2011a; Nicolsky and others, 2013; Nicolsky and others, 2014; Suleimani and others, 2010; Suleimani and others, 2013, 2015). Because the currently available digital elevation models (DEMs) for these southeast Alaska communities are of insufficient quality for high-resolution modeling, we follow the National Tsunami Hazard Mitigation Program (NTHMP, 2010) guidelines (nws.weather.gov/ nthmp/publications.html) for determining tsunami hazard zones for areas that have either low risk due to small population size and minimal infrastructure vulnerability, or do not have access to high-resolution elevation models. The tsunami hazard maps of Port Alexander, Craig, and Ketchikan are developed using the methodology described in detail in Suleimani and others (2018). In short, for four scenario earthquakes, we modeled water dynamics from source to community and computed maximum tsunami wave heights using the highest resolution grids available (see table 2). Each model run covers 12 hours of post-earthquake tsunami propagation to account for all waves in the wave train, as well as secondary (reflected) wave interactions. At every location throughout the high-resolution grids, the maximum tsunami height from any of the four earthquakes is saved, and we use these maximum values to extrapolate wave runup heights on land in a new, "composite" map of maximum wave heights that can be expected from the earthquake scenarios. 
Table 1. Tsunami effects at the three Southeast communities. Data from the National Centers for Environmental Information (NCEl; formerly known as National Geophysical Data Center [NGDC]) Global Historical Tsunami Database (doi.org/10.7289/V5PN93H7) and comments from Lander (1996).

\begin{tabular}{|c|c|c|c|c|}
\hline Date & Magnitude (MW) & Origin & $\begin{array}{l}\text { Maximum water } \\
\text { height in } \mathrm{m} \text { (in) }\end{array}$ & Comments \\
\hline \multicolumn{5}{|c|}{ Port Alexander } \\
\hline 09/29/2009 & 8.1 & Samoa Islands & $0.12(4.7)$ & \\
\hline $02 / 27 / 2010$ & 8.8 & Chile & $0.18(7.1)$ & \\
\hline 03/11//2011 & 9.0 & Honshu, Japan & $0.42(16.5)$ & \\
\hline $10 / 28 / 2012$ & 7.7 & Haida Gwaii & $0.11(4.3)$ & \\
\hline 05/01/2013 & 7.5 & Southeaster Alaska & $0.14(5.5)$ & \\
\hline \multicolumn{5}{|c|}{ Craig } \\
\hline 05/22/1960 & 9.5 & Chile & $1.0(3.2 \mathrm{ft})$ & Buoy was moved. \\
\hline 03/28/1964 & 9.2 & Gulf of Alaska & $4.2(13.8 \mathrm{ft})$ & \\
\hline $02 / 27 / 2010$ & 8.8 & Chile & $0.23(9.1)$ & \\
\hline 03/1//2011 & 9.0 & Honshu, Japan & $0.31(12.2)$ & \\
\hline \multicolumn{5}{|c|}{ Ketchikan } \\
\hline 08/22/1949 & 8.1 & Queen Charlotte Islands & $0.5(19.7)$ & $\begin{array}{l}\text { Water receded and rose } \\
\text { unexpectedly. }\end{array}$ \\
\hline 03/28/1964 & 9.2 & Gulf of Alaska & $0.6(23.6)$ & \\
\hline 03/11/2011 & 9.0 & Honshu, Japan & $0.11(4.3)$ & \\
\hline
\end{tabular}

\section{Computational Grids and Data Sources}

To develop a regional tsunami hazard map we use a series of nested computational grids. A nested grid allows for higher resolution in areas where it is needed without expending computer resources in areas where it is not. The bathymetric and topographic relief in each nested grid is based on DEMs developed at the NCEI. The extent of each grid used in this mapping project is shown in figure 3 and listed in table 2 . The coarsest grid, level 0 , with 2-arc-minute resolution, spans the central and northern Pacific Ocean. The bathymetric data for the 2-arc-minute-resolution grid is extracted from the ETOPO2 dataset (NGDC, 2006, doi. org/10.7289/V5J1012Q). We use two intermediate grids between the coarsest- and highest-resolution grids (table 2). The first intermediate grid of
24 arc-second resolution (level 1) was developed to accommodate the current tsunami mapping project for Port Alexander, Craig and Ketchikan, as well as other tsunami mapping efforts for many communities in Southeast Alaska (fig. 3). To develop 8/3-, 8 -, and 24-arc-second resolution grids, shoreline, bathymetric, and topographic digital datasets were obtained from several U.S. federal and academic agencies, including: NOAA's National Ocean Service, Office of Coast Survey, and NGDC; the U.S. Fish \& Wildlife Service (FWS); the U.S. Geological Survey (USGS); and the U.S. Army Corps of Engineers (USACE). All data were shifted to World Geodetic System 1984 (WGS 84) horizontal and Mean Higher High Water (MHHW) vertical datums. The data sources and methodology used to create the 24-, 8-, and 8/3-arc-second DEMs are described in greater detail in Caldwell and others (2012) and Lim and others (2011). 
Table 2. Nested grids used to compute propagation of tsunami waves generated in the Pacific Ocean to the three Southeast communities. The fine-resolution grids are used to compute the inundation. Note that the grid resolution in meters is not uniform and is used to illustrate grid fineness in the region. The first dimension is the longitudinal grid resolution; the second is the latitudinal resolution.

\begin{tabular}{|l|c|c|c|c|}
\hline \multirow{2}{*}{ Grid name } & \multicolumn{2}{|c|}{ Resolution } & \multirow{2}{*}{$\begin{array}{c}\text { West-East } \\
\text { boundaries }\end{array}$} & South-North boundaries \\
\cline { 2 - 5 } & Arc-seconds & Meters & $120^{\circ} 00^{\prime} \mathrm{E}-100^{\circ} 00^{\prime} \mathrm{W}$ & $10^{\circ} 00^{\prime} \mathrm{N}-65^{\circ} 00^{\prime} \mathrm{N}$ \\
\hline Level 0, Northern Pacific & $120 \times 120$ & $\approx 2,015 \times 3,700$ & $130^{\circ} 00^{\prime} \mathrm{W}-141^{\circ} 00^{\prime} \mathrm{W}$ & $54^{\circ} 00^{\prime} \mathrm{N}-60^{\circ} 00^{\prime} \mathrm{N}$ \\
\hline Level 1, Southeastern Alaska & $24 \times 24$ & $\approx 403 \times 740$ & $133^{\circ} 15^{\prime} \mathrm{W}-137^{\circ} 15^{\prime} \mathrm{W}$ & $55^{\circ} 45^{\prime} \mathrm{N}-59^{\circ} 36^{\prime} \mathrm{N}$ \\
\hline Level 2, Juneau West & $8 \times 8$ & $\approx 132 \times 246$ & $134^{\circ} 48^{\prime} 08^{\prime \prime} \mathrm{W}-130^{\circ} 47^{\prime} 32^{\prime \prime} \mathrm{W}$ & $54^{\circ} 36^{\prime} 14^{\prime \prime} \mathrm{N}-57^{\circ} 35^{\prime} 33^{\prime \prime} \mathrm{N}$ \\
\hline Level 2, Juneau East & $8 \times 8$ & $\approx 132 \times 246$ & $135^{\circ} 07^{\prime} 35^{\prime \prime} \mathrm{W}-134^{\circ} 24^{\prime} 34^{\prime \prime} \mathrm{W}$ & $56^{\circ} 00^{\prime} 33^{\prime \prime} \mathrm{N}-56^{\circ} 28^{\prime} 37^{\prime \prime} \mathrm{N}$ \\
\hline Level 3, Port Alexander & $8 / 3 \times 8 / 3$ & $\approx 45 \times 82$ & $133^{\circ} 59^{\prime} 06^{\prime \prime} \mathrm{W}-131^{\circ} 00^{\prime} 48^{\prime \prime} \mathrm{W}$ & $54^{\circ} 38^{\prime} 05^{\prime \prime} \mathrm{N}-56^{\circ} 38^{\prime} 25^{\prime \prime} \mathrm{N}$ \\
\hline Level 3, Craig/Ketchikan & $8 / 3 \times 8 / 3$ & $\approx 45 \times 82$ & & \\
\hline
\end{tabular}

One of the fine-resolution (level 3) grids covers Port Alexander, and a second one covers Craig and Ketchikan. The size of the fine-resolution grid cells, which is about $45 \times 82 \mathrm{~m}(148 \times 269 \mathrm{ft})$, satisfies NOAA's minimum recommended requirements for estimation of the tsunami hazard zone (NTHMP, 2010); however, no DEM verification efforts were conducted to reduce uncertainties in the fine-resolution (level 3) grids. Therefore, in this report we do not perform high-resolution runup modeling, but provide an estimation of the tsunami hazard zone by extrapolating the maximum composite tsunami wave height on land according to the tsunami scenarios described below. We account for uncertainties inherent to this method by applying a safety factor of 1.3 (Suleimani and others, 2018) to the estimated hazard zone.

\section{Tsunami Sources}

We use a deterministic approach for our earthquake and tsunami hazard modeling. We define the largest hypothetical, yet scientifically-defendable earthquake scenarios that could affect the communities and calculate the potential resulting tsunami inundation. Although we do not explicitly develop "worst-case" scenarios for each community, we develop our earthquake sources based on previous studies focused on maximum credible scenarios for coastal Alaska. For this study, we use three great earthquakes in the eastern part of the Alaska-Aleutian subduction zone that have been published in previous studies (Suleimani and others, 2013, 2015, 2016), as well as a rupture of the Cascadia subduction zone (Ross and others, 2013). This approach is distinctly different from probabilistic hazard analyses used for land-use planning or insurance estimates (Geist and Parsons, 2006). Probabilistic earthquake hazards consider all possible earthquakes (both large and small) and define the probability that an earthquake of a certain magnitude will occur in a given amount of time.

The tsunami scenarios for the three communities are outlined below. The vertical coseismic deformations for scenarios 1-4 are shown in figure 4 , and the main rupture parameters are listed in table 3 . 
Table 3. Significant credible tsunami sources for the three Southeast communities.

\begin{tabular}{|c|c|c|c|c|c|}
\hline \multicolumn{2}{|r|}{ Scenarios } & \multirow{2}{*}{$\begin{array}{c}\begin{array}{c}\text { Maximum slip, } \\
\mathrm{m}(\mathrm{ft})\end{array} \\
23(75)\end{array}$} & \multirow{2}{*}{$\begin{array}{c}\begin{array}{c}\text { Average slip, } \\
\text { m (ft) }\end{array} \\
15(49)\end{array}$} & \multirow{2}{*}{$\begin{array}{l}\text { Maximum regional } \\
\text { subsidence, } \mathrm{m}(\mathrm{ft})\end{array}$} & \multirow{2}{*}{$\begin{array}{c}\begin{array}{c}\text { Maximum region- } \\
\text { al uplift, } \mathrm{m}(\mathrm{ft})\end{array} \\
9(30)\end{array}$} \\
\hline 1 & $\begin{array}{l}M_{w} 9.3 \text { earthquake: the extended } \\
1964 \text { rupture }\end{array}$ & & & & \\
\hline 2 & $\begin{array}{l}\mathrm{M}_{\mathrm{w}} 9.0 \text { earthquake: the earthquake } \\
\text { in the } 1964 \text { rupture area with Tohoku- } \\
\text { type slip distribution. }\end{array}$ & $37(121)$ & $9(30)$ & $-4(-13)$ & $14(48)$ \\
\hline 3 & $\begin{array}{l}M_{w} 9.0 \text { earthquake: the SAFRR } \\
\text { tsunami scenario }\end{array}$ & 75 (246) & $16(52)$ & $-3(-9)$ & $15(49)$ \\
\hline 4 & $\begin{array}{l}M_{w} 9.0 \text { earthquake: rupture of the } \\
\text { Cascadia subduction zone }\end{array}$ & 45 (148) & $36(118)$ & $-8(-25)$ & $11(35)$ \\
\hline
\end{tabular}

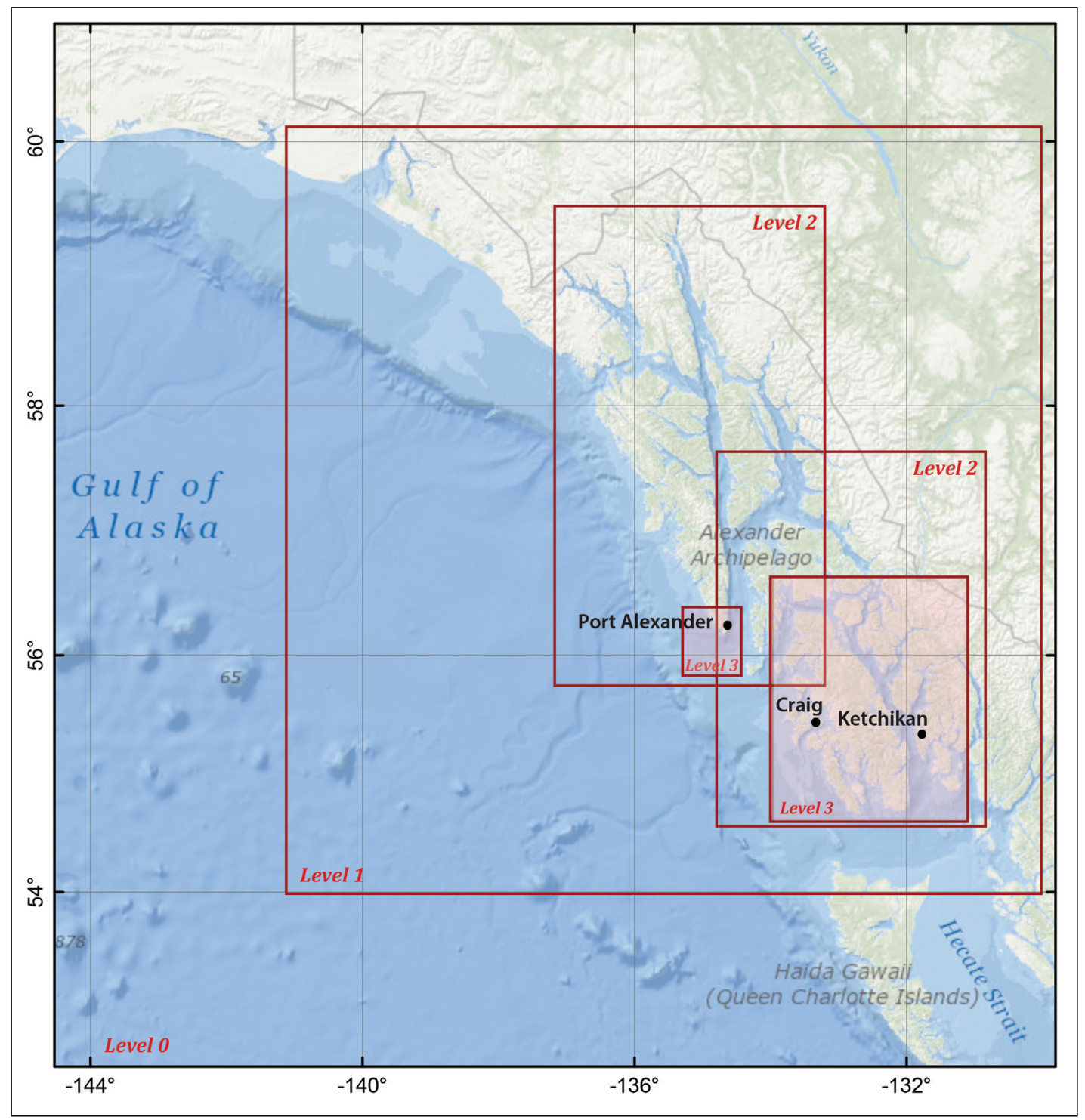

Figure 3. Nesting of the bathymetry/topography grids for numerical modeling of tsunami propagation and runup. The coarsest grid, level 0, covers the central and northern Pacific Ocean. The location of each embedded grid is marked by a red rectangle. Refer to table 2 for grid parameters. 
Scenario 1. $A M_{W} 9.3$ event: Extended 1964 rupture.

Scenario 2. $A M_{w} 9.2$ event: Earthquake in the 1964 rupture area with Tohokutype slip distribution.

Scenario 3. $A M_{W} 9.0$ event: The SAFRR tsunami scenario.

Scenario 4. $A \mathrm{M}_{\mathrm{w}} 9.0$ event: Rupture of the Cascadia subduction zone.
A $M_{W} 9.3$ earthquake that ruptures the aftershock area of the 1964 earthquake and, in addition, the Yakataga-Yakutat (YY) segment of the Alaska-Aleutian megathrust (fig. 1). Vertical displacements in the 1964 rupture zone are based on the coseismic deformation model by Johnson and others (1996). A detailed description of this scenario is provided in Suleimani and others (2013). Vertical coseismic deformations are shown in figure $4 \mathrm{~A}$.

$A M_{w} 9.2$ earthquake rupturing the eastern part of the Alaska-Aleutian megathrust. The slip is distributed almost uniformly along strike except for the edges of the rupture where the slip is tapered. In the downdip direction, the slip is concentrated on the shallow portion of the fault (near the seafloor trench), similar to the Tohoku 2011 earthquake (Ito and others, 2011). Suleimani and others (2013) give a detailed description of a sensitivity study to determine which parts of the eastern Alaska-Aleutian megathrust produce the highest tsunami amplitudes in southeast Alaska. Vertical coseismic deformations are shown in figure $4 \mathrm{~B}$.

$A M_{W} 9.0$ earthquake rupturing the Alaska-Aleutian megathrust south of the Alaska Peninsula, west of Kodiak Island in the aftershock zone of the 1938 earthquake (fig. 1). The USGS Science Application for Risk Reduction (SAFRR) project, in collaboration with NOAA and State of California agencies, developed this scenario for a tsunami inundation analysis in California (Ross and others, 2013). The earthquake is similar to the Tohoku 2011 event. Vertical coseismic deformations are shown in figure $4 \mathrm{C}$.

A $M_{W} 9.0$ earthquake rupturing the Cascadia subduction zone along the British Columbia, Washington, Oregon, and northern California coasts. A recent model by Witter and others (2011) suggests that the slip distribution in the down-dip direction is bell-shaped. In this report, the assumed $M_{W} 9.0$ rupture recovers 1,200 years' worth of plate convergence with about $36 \mathrm{~m}(118 \mathrm{ft}$ ) of maximum slip (Witter and others, 2011). Vertical coseismic deformations are shown in figure 4D. 
Scenario 1. $A M_{w} 9.3$ event: The extended 1964 rupture.

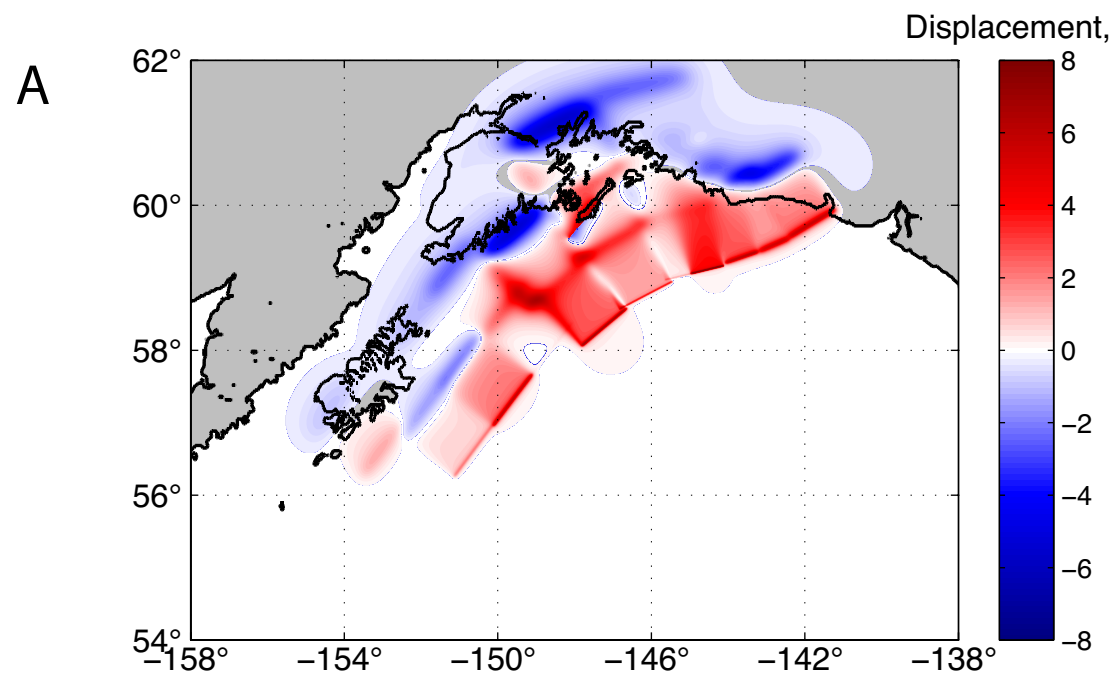

Scenario 2. $\mathrm{A} \mathrm{M}_{\mathrm{w}} 9.2$ event: The earthquake in the 1964 rupture area with Tohoku-type slip distribution.

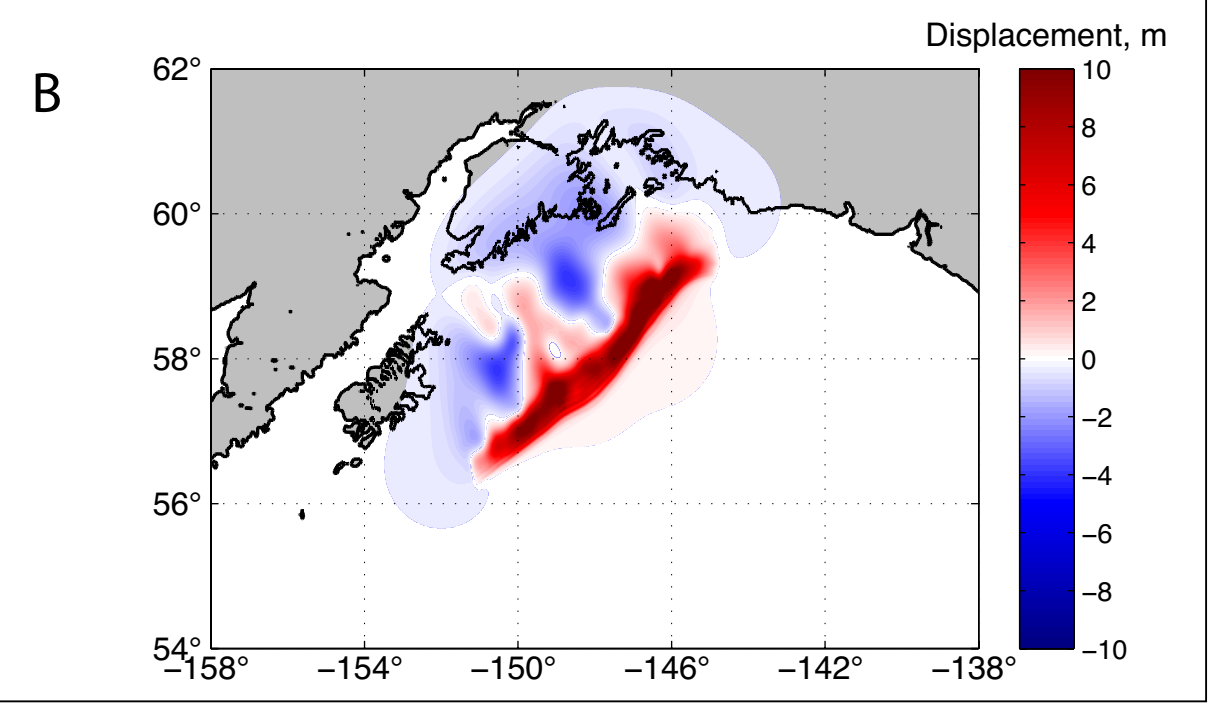

Figure 4. Vertical coseismic deformations corresponding to scenarios 1 and 2. Blue areas are associated with coseismic ground subsidence; areas of uplift are shown in red.

\section{Numerical Model of Tsunami Propagation and Runup}

The numerical model currently used by the Alaska Earthquake Center for tsunami inundation mapping is a nonlinear, flux-formulated, shallow-water model (Nicolsky and others, 2011b) that has been validated (NTHMP, 2012) through a set of analytical benchmarks and tested against laboratory and field data (Synolakis and others, 2007). The application of the model in Alaska, including its assumptions and limitations, are described in a number of previous studies (Nicolsky and others, 2014; Suleimani and others, 2015). Note that we use bathymetric data corresponding to the Mean Higher High Water (MHHW) tide level in southeast Alaska. 


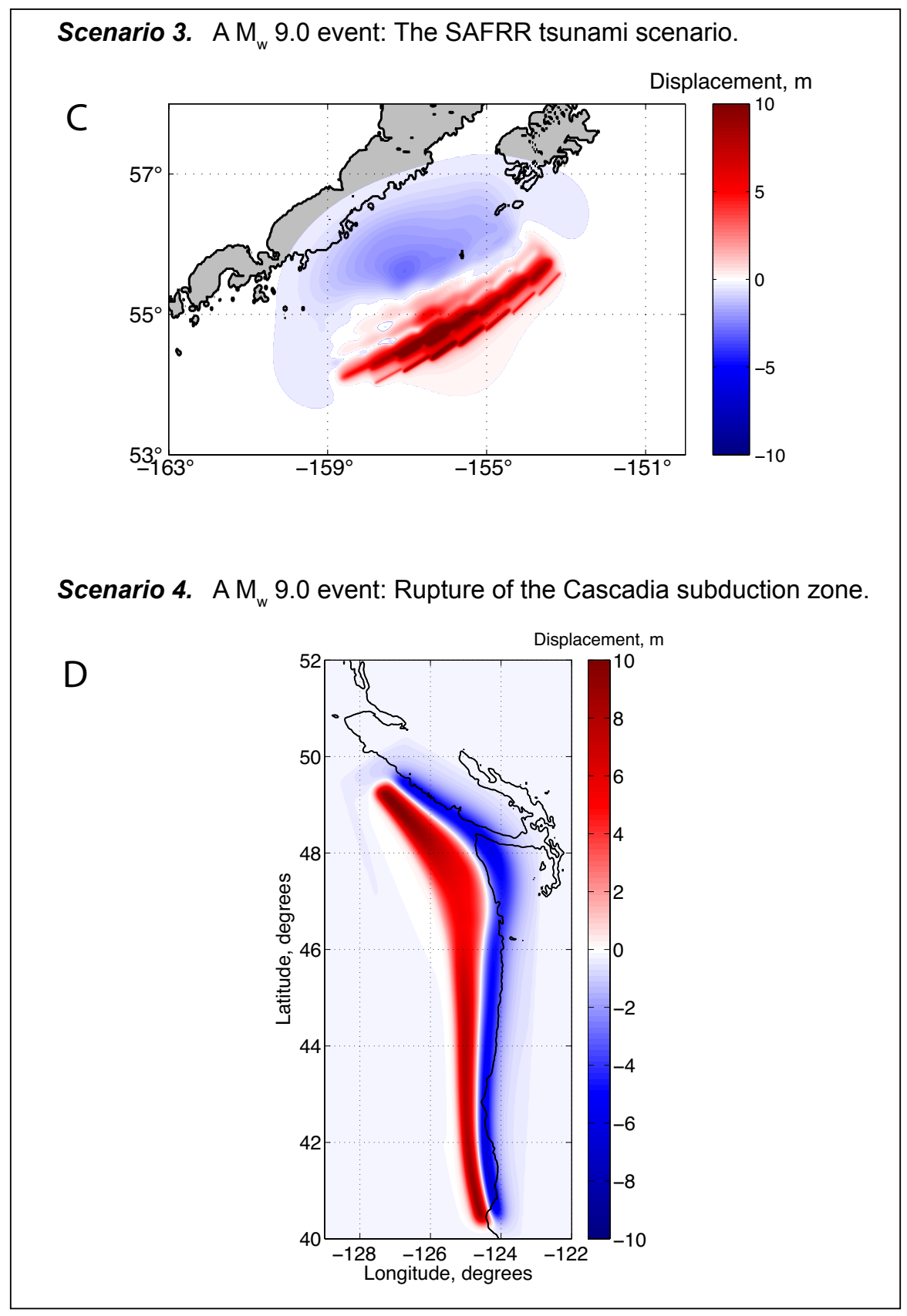

Figure 4, continued. Vertical coseismic deformations corresponding to scenarios 3 and 4 . Blue areas are associated with coseismic ground subsidence; areas of uplift are shown in red.

For each tsunami scenario, we first calculate the maximum tsunami wave heights in the highest-resolution grid over the course of the entire model run in the following way: at each grid point, the tsunami wave height is computed at every time step during the tsunami propagation time, and the maximum value is retained. Then we compute the composite maximum wave height from all considered scenarios by again choosing the maximum value for each grid point among all scenarios, and plot the results in the vicinity of the coastal community and surrounding waters.

\section{MODELING RESULTS}

We performed numerical calculations for all four tsunami sources. For each earthquake, we modeled the water dynamics in each grid listed in table 2, and computed maximum tsunami wave heights in the level 3 grids for Port 
Alexander, Craig, and Ketchikan. Each model run was performed for 12 hours of tsunami propagation to account for all waves in the wave train, as well as for secondary (reflected) waves. Figures 5 and 6 show the maximum tsunami heights for scenarios 1-4 in the Port Alexander and the Craig/Ketchikan level 3 grids, respectively. Scenario 2 produces the largest amplitudes in all three communities; scenario 1 also generates comparable wave heights at Craig, and scenario 4 produces the second largest wave at Ketchikan.
Figure 7 shows the maximum composite tsunami height for all scenarios calculated in the vicinity of each community. Table 4 summarizes all modeling results and provides the maximum value of the tsunami height for each community. We project this value, multiplied by a safety factor of 1.3, on land by drawing an elevation contour that corresponds to this height, which becomes the maximum estimated runup height. This contour approximates the boundary of the tsunami hazard zone, and should be used by emergency planners

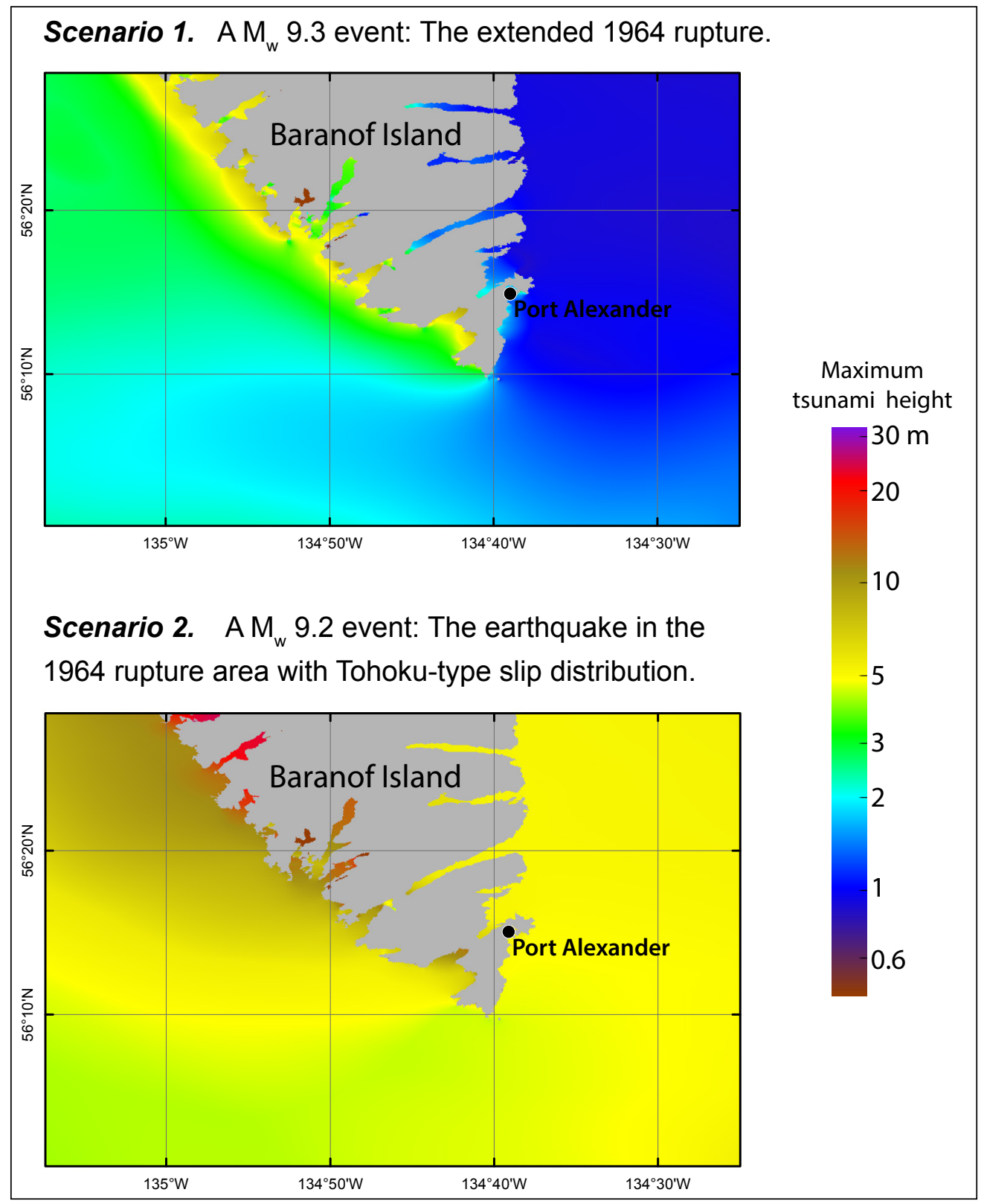

Figure 5A. Maximum tsunami heights for scenarios 1 and 2 in the Port Alexander level 3 grid. 
and public officials as a guide in tsunami mitigation activities.

Map sheets 1-3 illustrate approximate tsunami hazard maps for Port Alexander, Craig, and Ketchikan, respectively. For the communities of Port Alexander and Craig, we used the DCRA elevation datasets and referenced the DCRA elevation contours to the MHHW datum (Macpherson and others, 2014). For both communities, we selected the closest contour to the estimated maximum runup height and extracted it as the tsunami hazard boundary. The $4 \mathrm{~m}$ (13.1 ft) contour was extracted from the DCRA data for Port Alexander, and the $3.2 \mathrm{~m}(10.5 \mathrm{ft})$ contour was extracted for Craig. Where DRCA data are incomplete for a community, we infer contours based on available imagery or other, lower-resolution DEMs and use a different map symbol to represent these areas. The $1 \mathrm{~m}$ elevation contour for Ketchikan was generated from a $3 \mathrm{ft}$-resolution DEM based on the 2014 lidar data and shared by the FEMA Region 10 office (A. Siok, written commun., 2017). The original

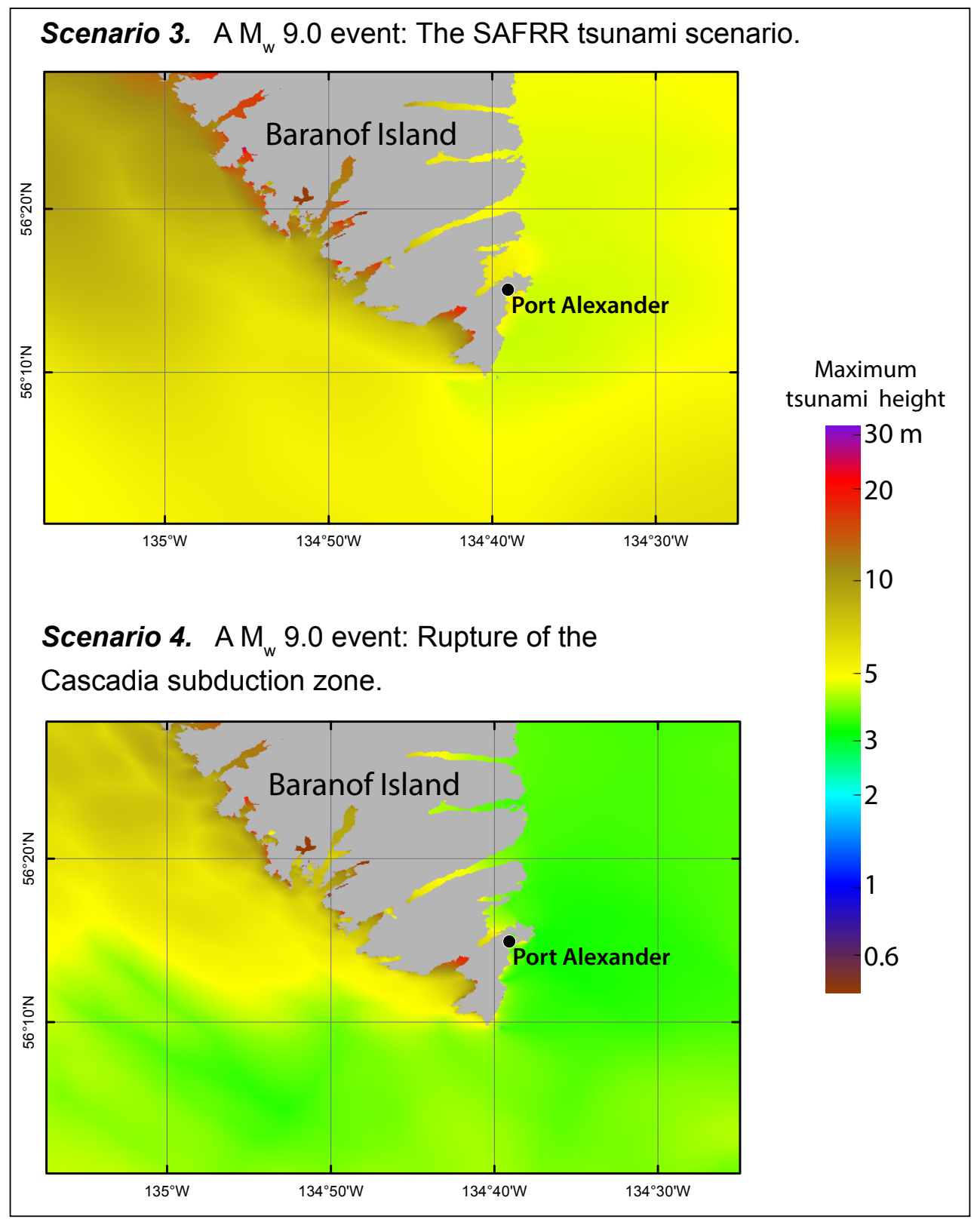

Figure 5B. Maximum tsunami heights for scenarios 3 and 4 in the Port Alexander level 3 grid. 
Table 4. Summary of tsunami modeling results for the three Southeast communities. Maximum assumed runup height is the maximum composed tsunami height multiplied by the safety factor of 1.3.

\begin{tabular}{|l|c|c|c|c|c|}
\hline \multicolumn{1}{|c|}{ Community } & $\begin{array}{c}\text { Maximum composite } \\
\text { tsunami height, } \mathbf{m}(\mathrm{ft})\end{array}$ & $\begin{array}{c}\text { Maximum } \\
\text { assumed runup } \\
\text { height, } \mathbf{m}(\mathrm{ft})\end{array}$ & $\begin{array}{c}\text { Composite } \\
\text { tsunami height }\end{array}$ & $\begin{array}{c}\text { Tsunami } \\
\text { hazard map }\end{array}$ & $\begin{array}{c}\text { Calculated } \\
\text { time series }\end{array}$ \\
\hline Port Alexander & $3(9.8)$ & $4(13.1)$ & Figure 7A & Map sheet 1 & Figure 8A \\
\hline Craig & $2.5(8.2)$ & $3.2(10.5)$ & Figure 7B & Map sheet 2 & Figure 8B \\
\hline Ketchikan & $0.77(2.5)$ & $1(3.3)$ & Figure 7C & Map sheet 3 & Figure 8C \\
\hline
\end{tabular}

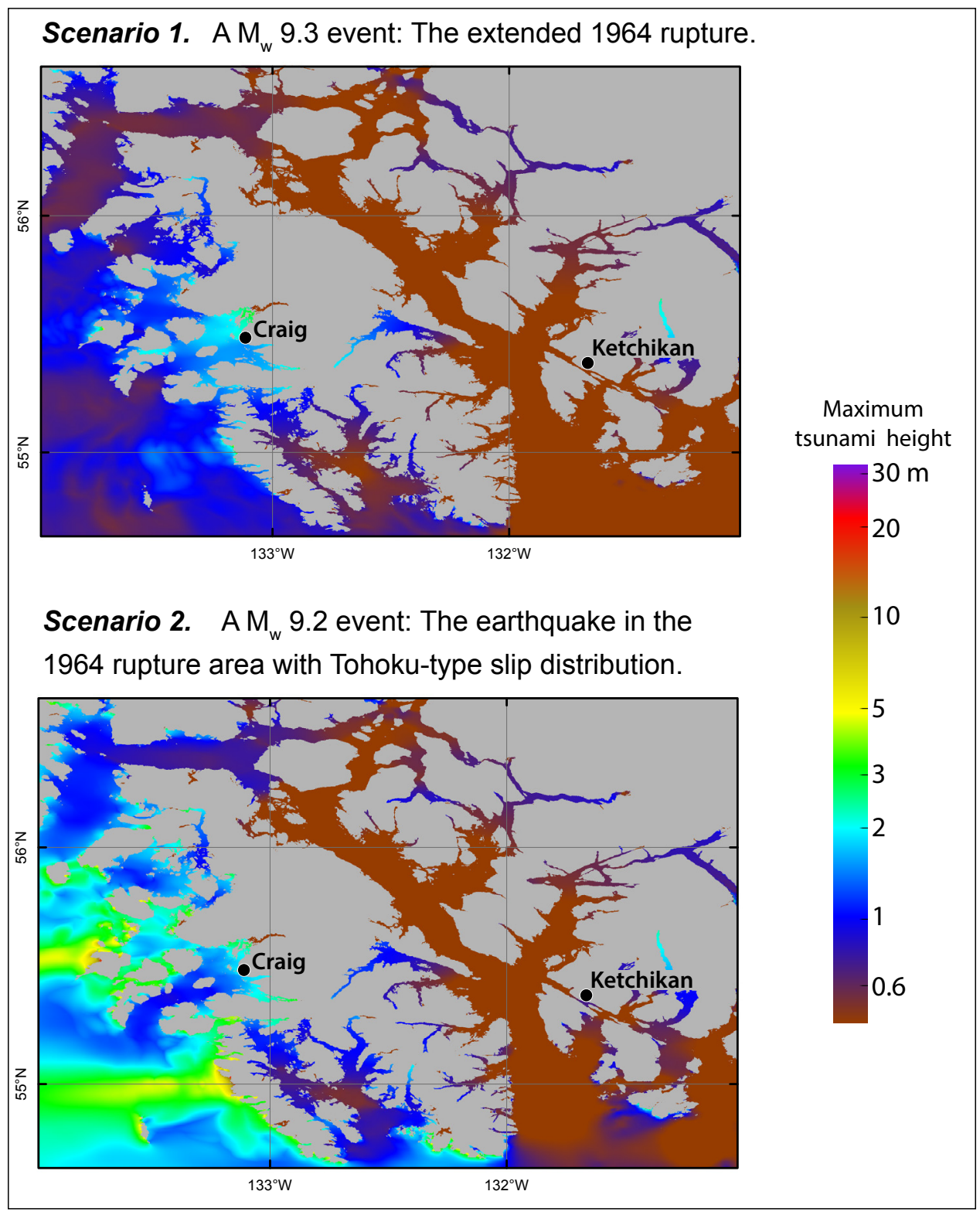

Figure 6A. Maximum tsunami heights for scenarios 1 and 2 in the Craig/Ketchikan level 3 grid. 
lidar DEM was converted from the NAVD88 vertical datum to the MHHW vertical datum by subtracting $1.1 \mathrm{~m}(3.6 \mathrm{ft})$ from the elevations. Refer to the metadata that accompanies this report for more details. The calculated maximum composite tsunami height at Ketchikan (table 4) did not result in visible inundation in town due to relatively low resolution of the level 3 grid. However, after application of the safety factor of 1.3 , the maximum assumed tsunami height was calculated as 1 meter. Therefore, the approximate tsunami hazard map for Ketchikan consists of the 1-meter elevation contour (map sheet 3).
It is important to note that previous high-resolution tsunami studies for Southeast Alaska communities (e.g., Suleimani and others, 2015) have demonstrated the dangers posed by tsunami waves generated by underwater landslides and subaerial rockfalls. That is to say, residents of Ketchikan and other Southeast Alaska communities should not disregard potential tsunami dangers if they experience moderate to severe earthquake shaking. Thick submarine layers of glacial sediments and steep, glacially-debuttressed fjord sidewalls are abundant in Southeast Alaska and prone

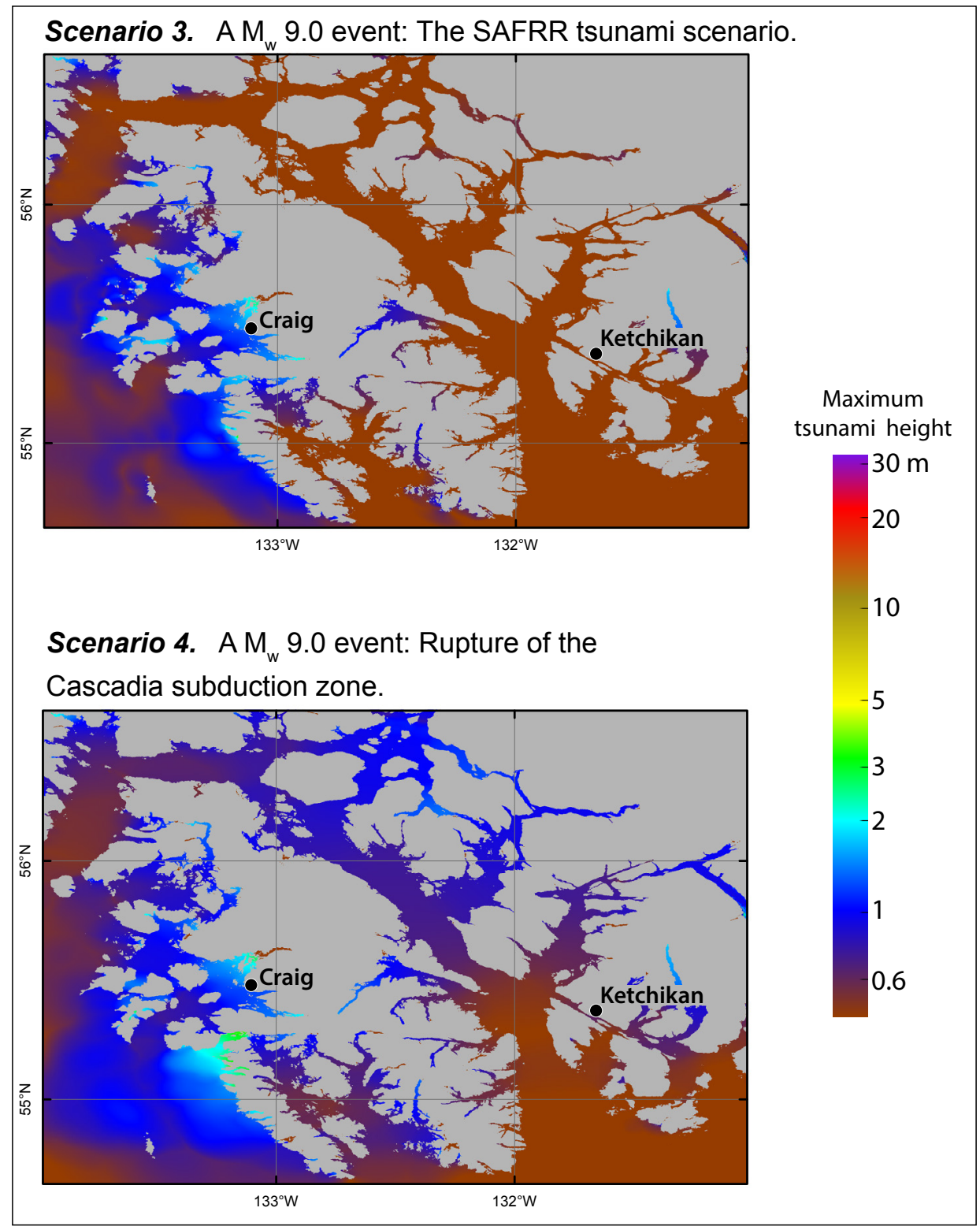

Figure 6B. Maximum tsunami heights for scenarios 3 and 4 in the Craig/Ketchikan level 3 grid. 


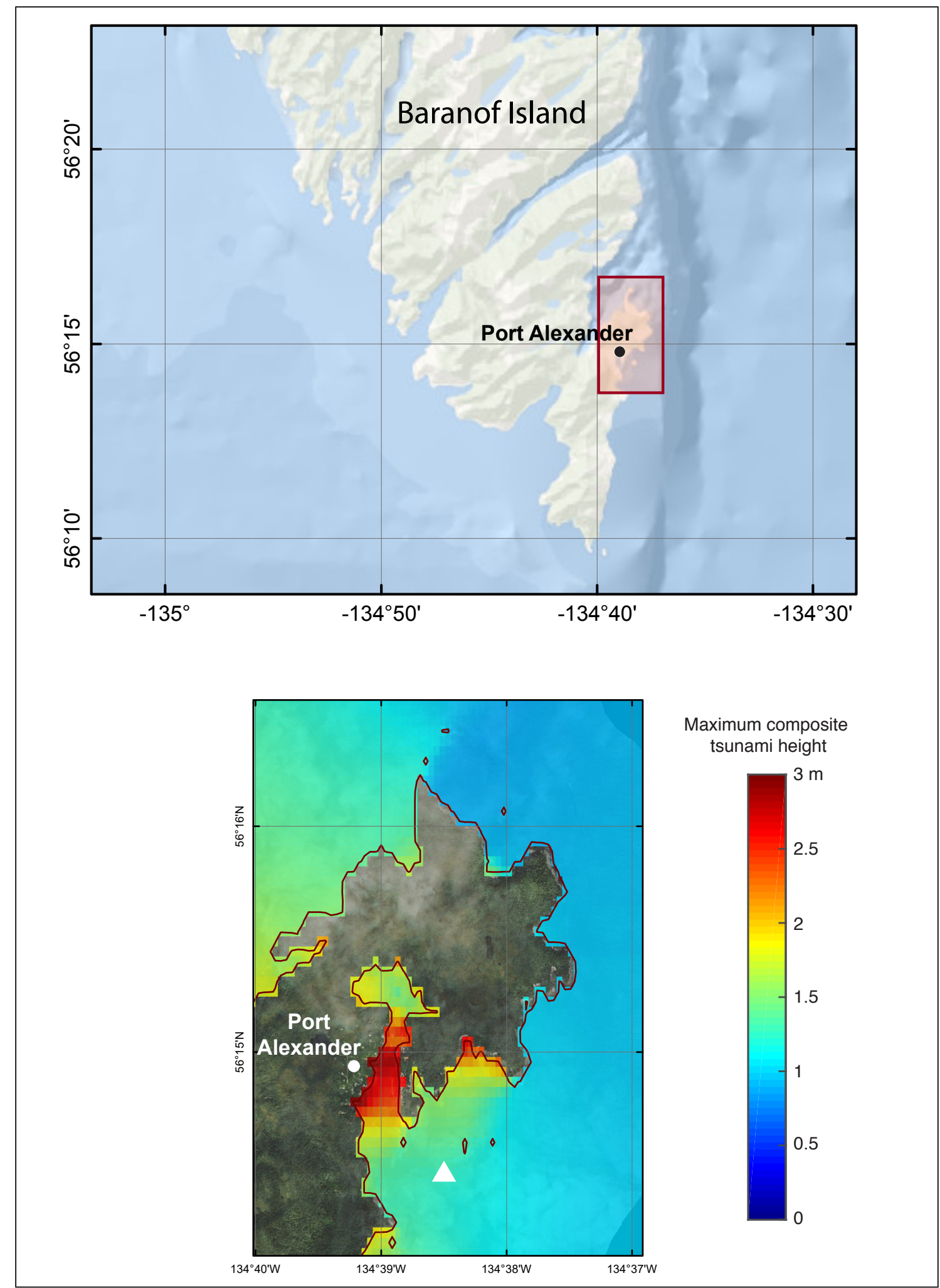

Figure 7A. Maximum composite tsunami height at Port Alexander. The white triangle indicates the location of the time series point, and the dark red line is the MHHW shoreline. The pink shaded rectangle in the upper map indicates the area shown in the lower map. 


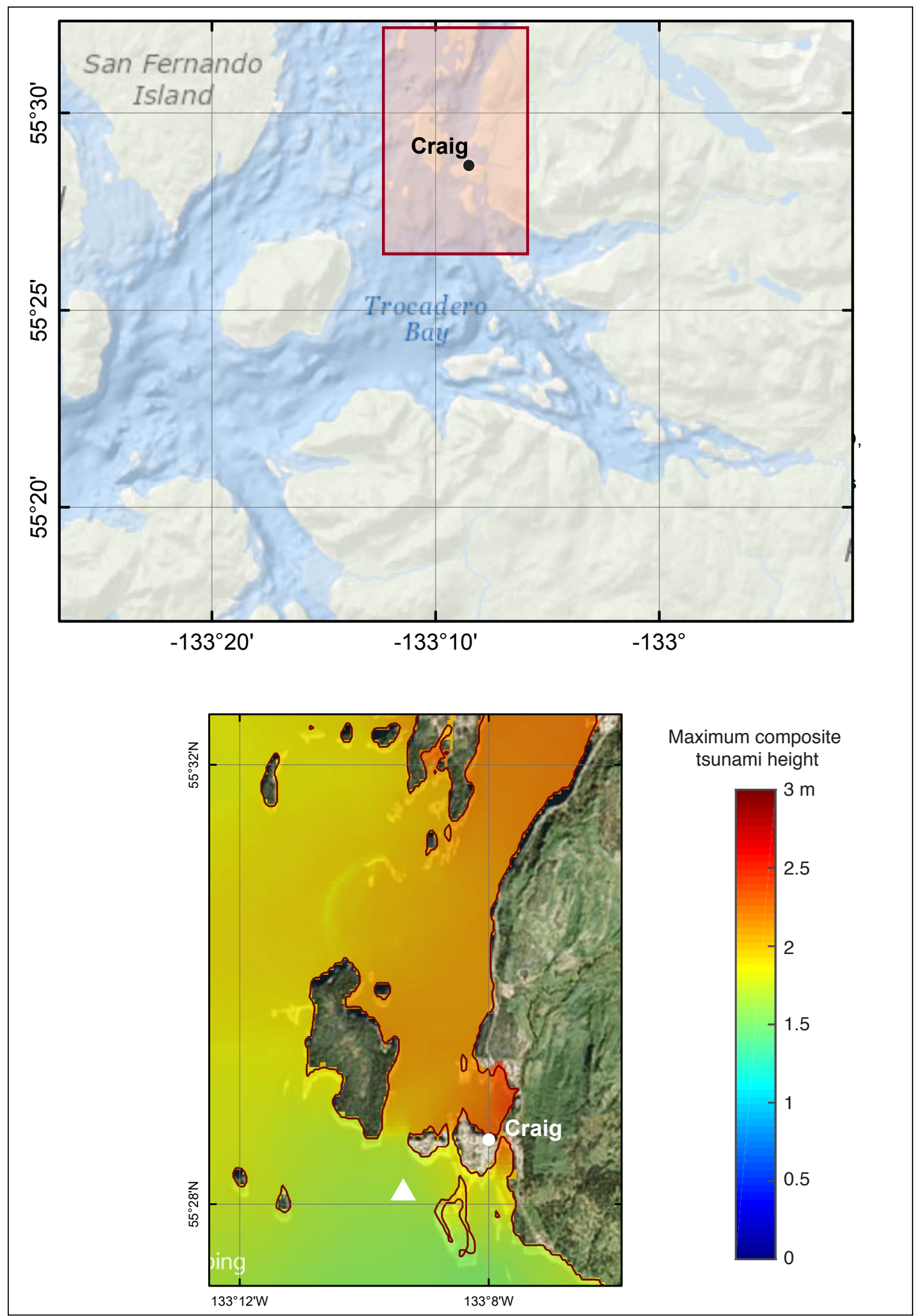

Figure 7B. Maximum composite tsunami height at Craig. The white triangle indicates the location of the time series point, and the dark red line is the MHHW shoreline. The pink shaded rectangle in the upper map indicates the area shown in the lower map. 

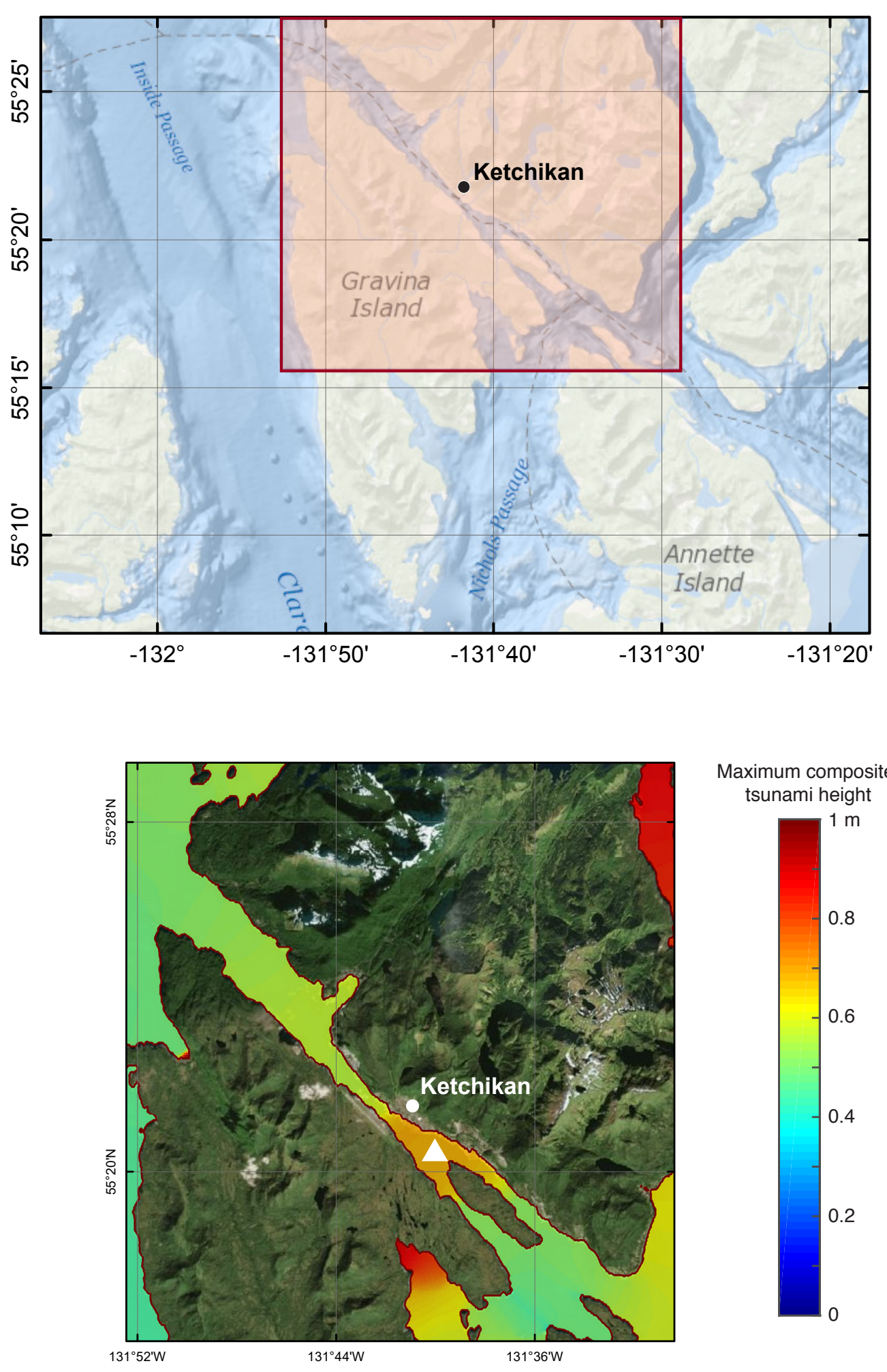

Maximum composite

tsunami height

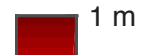

0.8

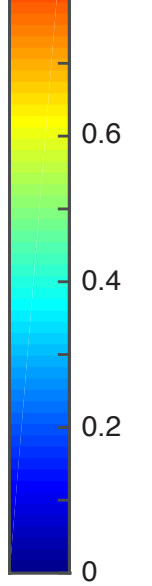

Figure 7C. Maximum composite tsunami height at Ketchikan. The white triangle indicates the location of the time series point, and the dark red line is the MHHW shoreline. The pink shaded rectangle in the upper map indicates the area shown in the lower map. 
to collapse-particularly during strong shaking associated with moderate to large earthquakes. Assessing the complete subaerial and submarine landslide hazards near Port Alexander, Craig, and Ketchikan is beyond the scope of this study, and therefore we do not model tsunamis generated by landslides. For a more comprehensive assessment of tsunami hazards in Southeast Alaska, future studies should gather data on the locations and volumes of potential mass failures near communities.

To help emergency managers understand the duration of tsunami hazards after large earthquakes, we supplement the hazard maps with the time series of the modeled water level at a near-shore location in each community (white triangles in figures 7A-7C). Time series plots are shown in figure 8 , with zero time corresponds to the time when the earthquake occurs. Analysis of the time series plot shows that amplitudes of tsunami waves at Port Alexander decrease significantly after about four hours of the arrival of the first wave, while at Craig and Ketchikan the decrease in amplitude is not substantial.

\section{SUMMARY}

We numerically model tsunami waves generated by local hypothetical earthquake sources, analyze tsunami wave dynamics, and develop approximate tsunami hazard maps for Port Alexander, Craig, and Ketchikan. We compute the composite maximum wave height from all considered scenarios and follow NTHMP guidelines to extrapolate the modeling data on land for estimation of tsunami inundation. The maximum runup heights are $4 \mathrm{~m}(13.1 \mathrm{ft})$ in
Port Alexander, $3.2 \mathrm{~m}(10.5 \mathrm{ft})$ in Craig, and $1 \mathrm{~m}$ $(3.3 \mathrm{ft})$ in Ketchikan.

Tsunami inundation approximations shown on the tsunami hazard maps have been completed using the best information available and are believed to be accurate; however, their preparation required many assumptions. In this assessment, we estimate the potential tsunami inundation zone based on four significant characteristic tsunami scenarios. Hence, the modeled tsunami inundation cannot be considered exhaustive, but the modeling results are still thought to provide a sound approximation to the potential tsunami inundation zone in each community.

Actual conditions during a tsunami may differ from the scenarios considered here due to variations in the source earthquakes, tides, and coastline infrastructure. These areas of maximum expected inundation are intended to assist in planning tsunami evacuation and response activities. Results are not suitable for land-use regulation or building-code development.

\section{ACKNOWLEDGMENTS}

This project, which is part of the National Tsunami Hazard Mitigation Program (NTHMP), received support from the National Oceanic and Atmospheric Administration (NOAA) under Reimbursable Services Agreement ADN 952011 with the State of Alaska's Division of Homeland Security \& Emergency Management (a division of the Department of Military and Veterans Affairs). 
A

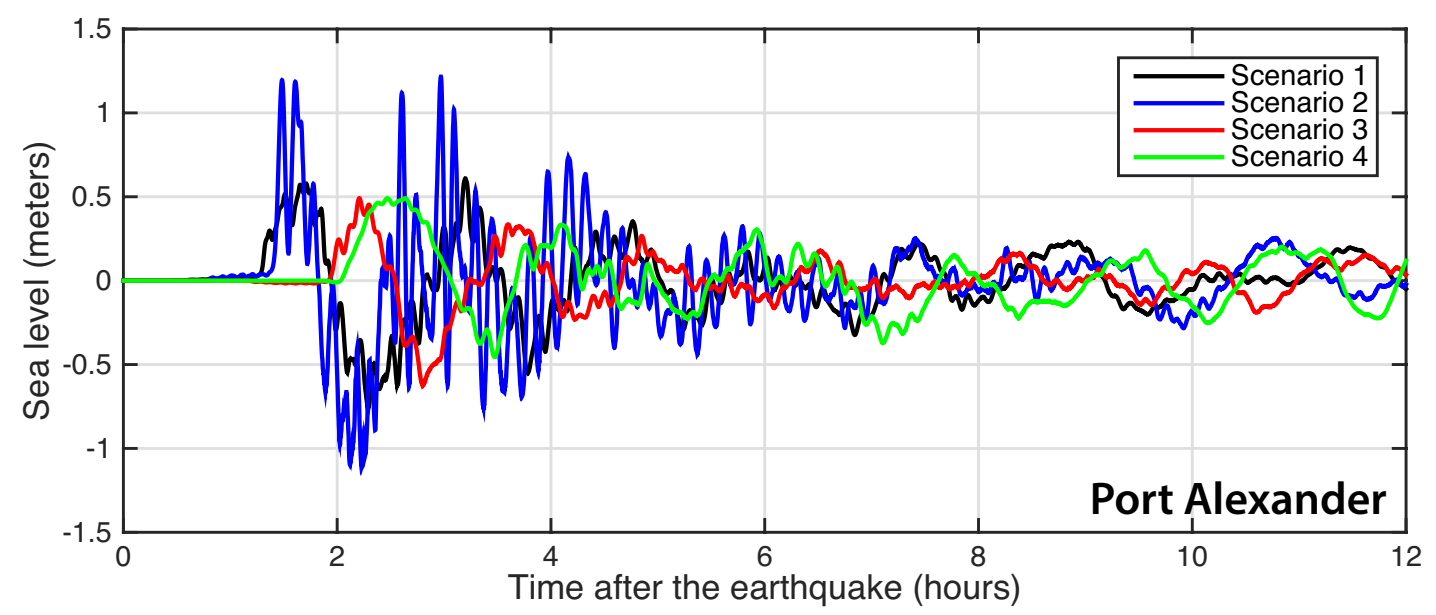

B

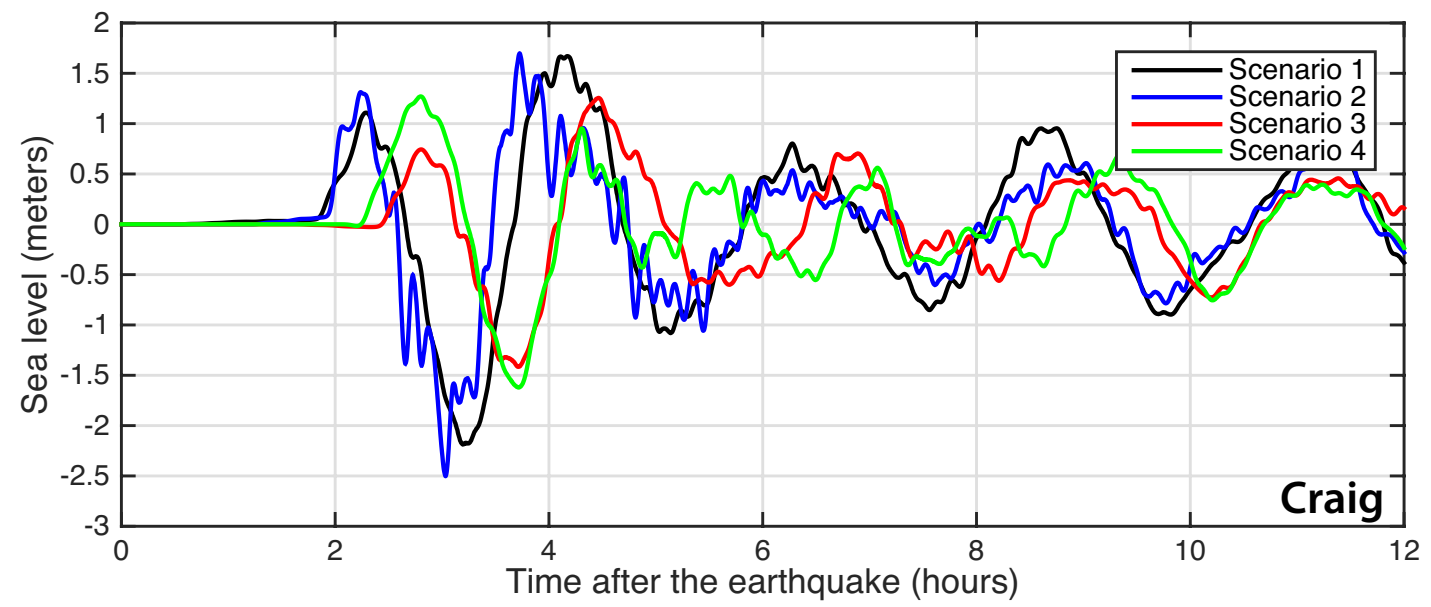

C

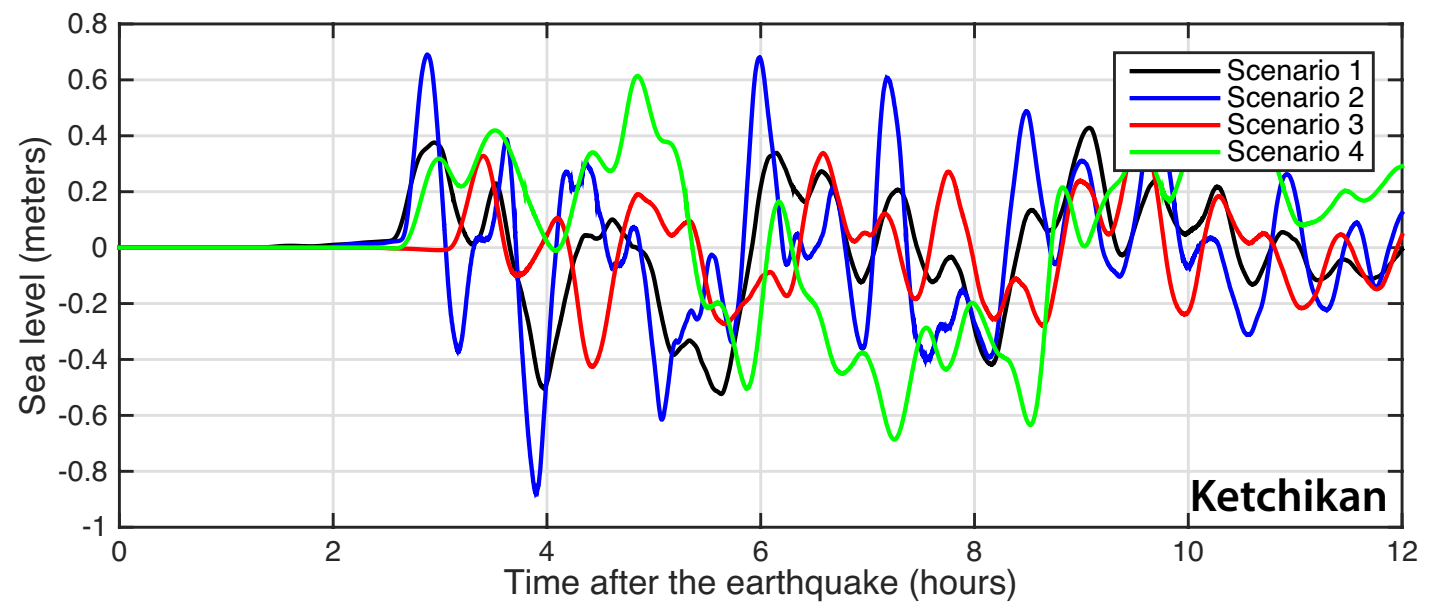

Figure 8. Time series of water level for scenarios 1-4 at (A) Port Alexander, (B) Craig, and (C) Ketchikan, calculated at the locations marked by white triangles in figures $7 \mathrm{~A}-\mathrm{C}$. 


\section{REFERENCES}

Alaska Department of Commerce, Community and EconomicDevelopment, Division ofCommunity and Regional Affairs (DCCED/DCRA), 2013. dcra-cdo-dcced.opendata.arcgis.com/

Caldwell, R.J., Taylor, L.A., Eakins, B.W., Carignan, K.S., and Collins, S.V., 2012, Digital elevation models of Juneau and Southeast AlaskaProcedures, data sources and analysis: National Geophysical Data Center, NOAA Technical Memorandum NESDIS NGDC-53, 66 p.

Carver, G.A., and Plafker, George, 2008, Paleoseismicity and neotectonics of the Aleutian subduction zone-An overview, in Freymueller, J.T., Haeussler, P.J., Wesson, R.L., and Ekström, Göran, eds., Active tectonics and seismic potential of Alaska: Washington, D.C., American Geophysical Union Geophysical Monograph, v. 179, p. 43-63. doi.org/10.1029/179GM02

Dunbar, P.K., and Weaver, C.S., 2008, U.S. states and territories national tsunami hazard assessment-Historical record and sources for waves: Technical Report, National Oceanic and Atmospheric Administration and U.S. Geological Survey, 59 p. nthmp.tsunami.gov/documents/ Tsunami_Assessment_Final.pdf

Estabrook, C.H., Jacob, K.H., and Sykes, L.R., 1994, Body wave and surface wave analysis of large and great earthquakes along the eastern Aleutian arc, 1923-1993; Implications for future events: Journal of Geophysical Research, v. 99, no. B6, p. 11,643-11,662.

Geist. L.G., and Parsons, T., 2006, Probabilistic analysis of tsunami hazards: Natural Hazards, v. 37, no. 3, p. 277-314. doi.org/10.1007/s11069005-4646-z

Ito, Yoshihiro, Tsuji, Takeshi, Osada, Yukihito, Kido, Motoyuki, Inazu, Daisuke, Hayashi, Yutaka, Tsushima, Hiroaki, Hino, Ryota, and Fujimoto, Hiromi, 2011, Frontal wedge deformation near the source region of the 2011 Tohoku-Oki earthquake: Geophysical Research Letters, v. 38, no. 7. doi.org/10.1029/2011GL048355

Johnson, J.M., Satake, Kenji, Holdahl, S.R., and Sauber, Jeanne, 1996, The 1964 Prince
William Sound earthquake-Joint inversion of tsunami waveforms and geodetic data: Journal of Geophysical Research, v. 101, no. B1, p. 523532. doi.org/10.1029/95JB02806

Johnson, J.M., Tanioka, Yuichiro, Ruff, L.J., Satake, Kenji, Kanamori, Hiroo, and Sykes, L.R., 1994, The 1957 great Aleutian earthquake, Pure and Applied Geophysics, v. 142, no. 1, p. 3-28. doi.org/10.1007/BF00875966

Kanamori, Hiroo, 1970, The Alaska earthquake of 1964; Radiation of long-period surface waves and source mechanism: Journal of Geophysical Research, v. 75, no. 26, p. 5,029-5,040.

Lander, J.F., 1996, Tsunamis affecting Alaska, 1737-1996: Boulder, CO, National Oceanic and Atmospheric Administration, National Geophysical Data Center (NGDC), Key to Geophysical Research Documentation, v. 31, 155 p.

Leonard, L.J., and Bednarski, J.M., 2015, The preservation potential of coastal coseismic and tsunami evidence observed following the 2012 $\mathrm{M}_{\mathrm{W}} 7.8$ Haida Gwaii thrust earthquake, in 2012 Haida Gwaii and 2013 Craig earthquakes at the Pacific North America plate boundary (British Columbia and Alaska), Bulletin of the Seismological Society of America, v. 105, no. 2B, p. 1,280-1,289. doi.org/10.1785/0120140193

Lim, E., Eakins, B.W., and Wigley, R., 2011, Coastal relief model of southern Alaska; Procedures, data sources and analysis: NOAA Technical Memorandum NESDIS NGDC-43, 22 p.

Lopez, A.M., and Okal, E.A., 2006, A seismological reassessment of the source of the 1946 Aleutian 'tsunami' earthquake: Geophysical Journal International, v. 165 , no. 3, p. 835-849. doi.org/10.1111/j.1365-246X.2006.02899.x

Macpherson, A.E., Nicolsky, D.J., and Suleimani, E.N., 2014, Digital elevation models of Skagway and Haines, Alaska: Procedures, data sources, and quality assessment: Alaska Division of Geological \& Geophysical Surveys Miscellaneous Publication 155, 15 p. doi.org/10.14509/29143

Miller, D.J., 1960, The Alaska earthquake of July 10, 1958-Giant wave in Lituya Bay: Bulletin of the Seismological Society of America, v. 50, no. 2, p. 253-266. 
National Geophysical Data Center (NGDC), 2006, 2-minute Gridded Global Relief Data (ETOPO2) v2: National Geophysical Data Center (NGDC), National Oceanic and Atmospheric Administration (NOAA). doi.org/10.7289/V5J1012Q

National Geophysical Data Center/World Data Service (NGDC/WDS), continuously updated, Global historical tsunami database at NGDC, $2100 \mathrm{BC}$ to present (interactive map): National Oceanic and Atmospheric Administration (NOAA), National Geophysical Data Center (NGDC). doi.org/10.7289/V5PN93H7

National Tsunami Hazard Mapping Program (NTHMP), 2010, Guidelines and best practices for tsunami inundation modeling for evacuation planning: National Oceanic and Atmospheric Administration (NOAA), NTHMP Mapping \& Modeling Subcommittee.

2012, Proceedings and results of the 2011 NTHMP Model Benchmarking Workshop: Boulder, CO, U.S. Department of Commerce/ NOAA/NTHMP, NOAA Special Report, 436 p. nthmp.tsunami.gov

Nicolsky, D.J., Suleimani, E.N., Combellick, R.A., and Hansen, R.A., 2011a, Tsunami inundation maps of Whittier and western Passage Canal, Alaska: Alaska Division of Geological \& Geophysical Surveys Report of Investigation 2011-7, 65 p. doi.org/10.14509/23244

Nicolsky, D.J., Suleimani, E.N., Haeussler, P.J., Ryan, H.F., Koehler, R.D., Combellick, R.A., and Hansen, R.A., 2013, Tsunami inundation maps of Port Valdez, Alaska: Alaska Division of Geological \& Geophysical Surveys Report of Investigation 2013-1, 77 p., 1 sheet, scale 1:12,500. doi.org/10.14509/25055

Nicolsky, D.J., Suleimani, E.N., and Hansen, R.A., 2011b, Validation and verification of a numerical model for tsunami propagation and runup: PUre and Applied Geophysics, v. 168, p. 1,199-1,222. doi.org/10.1007/s00024-010-0231-9

Nicolsky, D.J., Suleimani, E.N., and Koehler, R.D., 2014, Tsunami inundation maps of Cordova and Tatitlek, Alaska: Alaska Division of Geological \& Geophysical Surveys Report of Investigation
2014-1, 49 p. doi.org/10.14509/27241

Page, R.A., 1973, The Sitka, Alaska, earthquake of 1972: Earthquake Information Bulletin, v. 5, p. 4-9.

Ross, S.L., Jones, L.M., Miller, Kevin, P., K.A., Wein, A., Wilson, Ri.I., Bahng, B., Barberopoulou, A., Borrero, J.C., Brosnan, D.M., Bwarie, J.T., Geist, E.L., Johnson, L.A., Kirby, S.H., Knight, W.R., Long, K., Lynett, P., Mortensen, C.E., Nicolsky, D.J., Perry, S.C., Plumlee, G.S., Real, C.R., Ryan, K., Suleimani, E., Thio, H., Titov, V.V., Whitmore, P.M. and Wood, N.J., 2013, SAFRR (Science Application for Risk Reduction) Tsunami Scenario-Chapter A, Executive Summary and Introduction, in Ross, S.L., and Jones, L.M., eds., The SAFRR Tsunami Scenario: U.S. Geological Survey Open-File Report 2013-1170, p. 1-17. pubs.usgs.gov/of/2013/1170/a/

Suleimani, E.N., Nicolsky, D.J., and Koehler, R.D., 2013, Tsunami inundation maps of Sitka, Alaska: Alaska Division of Geological \& Geophysical Surveys Report of Investigation 2013-3, 76 p., 1 sheet, scale 1:250,000. doi.org/10.14509/26671

Suleimani, E.N., Nicolsky, D.J., and Koehler, R.D., 2015, Tsunami inundation maps of Elfin Cove, Gustavus and Hoonah, Alaska: Alaska Division of Geological \& Geophysical Surveys Report of Investigation 2015-1, 79 p. doi.org/10.14509/29404

Suleimani, E.N., Nicolsky, D.J., and Koehler, R.D., 2016, Tsunami inundation maps for Yakutat, Alaska: Alaska Division of Geological \& Geophysical Surveys Report of Investigation 2016-2, 47 p. doi.org/10.14509/29577

Suleimani, E.N., Nicolsky, D.J., Koehler, R.D., and Salisbury, J.B., 2018, Regional tsunami hazard assessment for Andreanof Islands, Alaska: Alaska Division of Geological \& Geophysical Surveys Report of Investigation 2017-2, 19 p., 2 sheets. doi.org/10.14509/29704

Suleimani, E.N., Nicolsky, D.J., West, D.A., Combellick, R.A., and Hansen, R.A., 2010, Tsunami inundation maps of Seward and Northern Resurrection Bay, Alaska: Alaska Division of Geological \& Geophysical Surveys Report of Investigation 2010-1, 47 p., 3 sheets, scale 1:12,500. doi.org/10.14509/21001 
Sykes, L.R., 1971, Aftershockzones ofgreatearthquakes, seismicity gaps, and earthquake prediction for Alaska and the Aleutians: Journal of Geophysical Research, v. 76, no. 32, p. 8,021-8,041.

Synolakis, C.E., Bernard, E.N., Titov, V.V., Kânoğlu, U., and González, F.I., 2007, Standards, criteria, and procedures for NOAA evaluation of tsunami numerical models: Seattle, WA, NOAA/Pacific Marine Environmental Laboratory, Technical Memorandum OAR PMEL-135, 55 p.

Tocher, Don, 1960, The Alaska earthquake of July 10, 1958-Movement on the Fairweather fault and field investigation of southern epicentral region: Bulletin of the Seismological Society of America, v. 50, no. 2, p. 267-292.

Witter, R.C.; Zhang, Y.; Wang, K.; Priest, G.R.; Goldfinger, C.; Stimely, L.L.; English, J.T.; and Ferro, P.A.; 2011, Simulating tsunami inundation at Bandon, Coos County, Oregon, using hypothetical Cascadia and Alaska earthquake scenarios: Oregon Department of Geology and Mineral Industries Special Paper 43, 57 p.

Wu, F.T., and Kanamori, Hiroo, 1973, Source mechanism of February 4, 1965, Rat Island earthquake: Journal of Geophysical Research, v. 78 , no. 26, p. 6,082-6,092. 